\title{
Engineering SARS-CoV-2 using a reverse genetic system
}

\author{
Xuping Xie $\odot^{1,8}$, Kumari G. Lokugamage ${ }^{2,8}$, Xianwen Zhang ${ }^{1,8}$, Michelle $\mathrm{N} . \mathrm{Vu}^{2}$, \\ Antonio E. Muruato ${ }^{1,2}$, Vineet D. Menachery $\oplus^{2,3,4 凶}$ and Pei-Yong Shi $\oplus^{1,3,5,6,7 凶}$
}

Reverse genetic systems are a critical tool for studying viruses and identifying countermeasures. In response to the ongoing COVID-19 pandemic, we recently developed an infectious complementary DNA (CDNA) clone for severe acute respiratory syndrome coronavirus 2 (SARS-CoV-2). The reverse genetic system can be used to rapidly engineer viruses with desired mutations to study the virus in vitro and in vivo. Viruses can also be designed for live-attenuated vaccine development and engineered with reporter genes to facilitate serodiagnosis, vaccine evaluation and antiviral screening. Thus, the reverse genetic system of SARS-CoV-2 will be widely used for both basic and translational research. However, due to the large size of the coronavirus genome $(\sim 30,000$ nucleotides long) and several toxic genomic elements, manipulation of the reverse genetic system of SARS-COV-2 is not a trivial task and requires sophisticated methods. Here, we describe the technical details of how to engineer recombinant SARS-CoV-2. Overall, the process includes six steps: (i) prepare seven plasmids containing SARS-CoV-2 cDNA fragment(s), (ii) prepare high-quality DNA fragments through restriction enzyme digestion of the seven plasmids, (iii) assemble the seven cDNA fragments into a genome-length cDNA, (iv) in vitro transcribe RNA from the genome-length cDNA, (iv) electroporate the genome-length RNA into cells to recover recombinant viruses and (vi) characterize the rescued viruses. This protocol will enable researchers from different research backgrounds to master the use of the reverse genetic system and, consequently, accelerate COVID-19 research.

Introduction

The emergence of SARS-CoV-2 at the end of 2019 initiated a worldwide pandemic that continues to threaten the global economy and public health ${ }^{1}$. To combat this newly emerged coronavirus, we have developed a reverse genetic system to generate recombinant viruses to characterize the biology of SARS-CoV-2 and develop vaccines and therapeutics (Fig. 1) ${ }^{2-4}$. The SARS-CoV-2 infectious complementary DNA (cDNA) clone utilizes an in vitro ligation approach that was pioneered with other coronaviruses, including transmissible gastroenteritis virus (TGEV), mouse hepatitis virus (MHV), and the original severe acute respiratory syndrome coronavirus (SARS-CoV) ${ }^{5-7}$. Our infectious cDNA clone-derived SARS-CoV-2 (icSARS-CoV-2) recapitulates the plaque morphology, viral RNA profile and replication kinetics of the original clinical isolate (strain SARS-CoV-2 WA1) ${ }^{8}$. In addition, we have generated a reporter virus that stably expresses a fluorescent reporter protein (mNeonGreen) and nanoluciferase (Nanoluc) to facilitate therapeutics discovery and vaccine evaluation ${ }^{2-4}$. The infectious cDNA clone has also been used to study the viral elements important for SARS-CoV-2 pathogenesis ${ }^{9,10}$. Together, this reverse genetic system offers a critical tool in the study of SARS-CoV2 and for countermeasure development. In this report, we describe the technical information and detailed protocols for utilizing this reverse genetic tool.

Development of the protocol

With the rapid spread of SARS-CoV-2, researchers around the world initiated efforts to respond to the COVID-19 pandemic. The technical requirement for the assembly of full-genome coronavirus cDNA is challenging because of the large genomic size ( $\sim 30,000$ nucleotides), toxic genomic regions and issues with mutations and deletions in the viral sequence ${ }^{11}$.

\footnotetext{
1Department of Biochemistry and Molecular Biology, University of Texas Medical Branch, Galveston, TX, USA. ${ }^{2}$ Department of Microbiology and Immunology, University of Texas Medical Branch, Galveston, TX, USA. ${ }^{3}$ Institute for Human Infection and Immunity, University of Texas Medical Branch, Galveston, TX, USA. ${ }^{4}$ Center for Biodefense \& Emerging Infectious Diseases, University of Texas Medical Branch, Galveston, TX, USA. ${ }^{5}$ Sealy Institute for Vaccine Sciences, University of Texas Medical Branch, Galveston, TX, USA. ${ }^{6}$ Sealy Center for Structural Biology \& Molecular Biophysics, University of Texas Medical Branch, Galveston, TX, USA. ${ }^{7}$ Department of Pharmacology \& Toxicology, University of Texas Medical Branch, Galveston, TX, USA. ${ }^{8}$ These authors contributed equally: Xuping Xie, Kumari G. Lokugamage, Xianwen Zhang. ${ }^{{ }^{2}}$-mail: vimenach@UTMB.edu; peshi@UTMB.edu
} 
SARS-CoV-2 genome

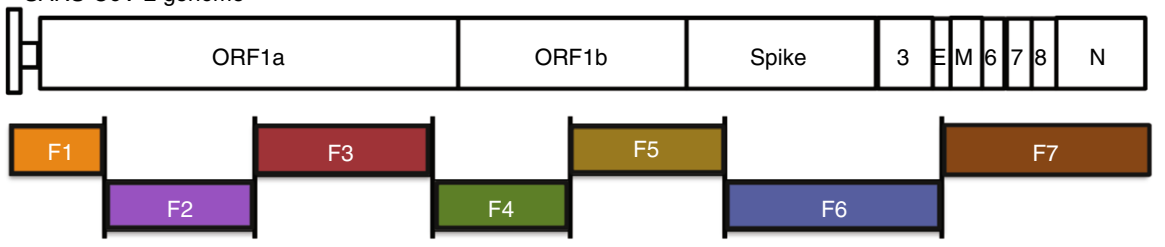

Stage 1: design \& bacterial amplification

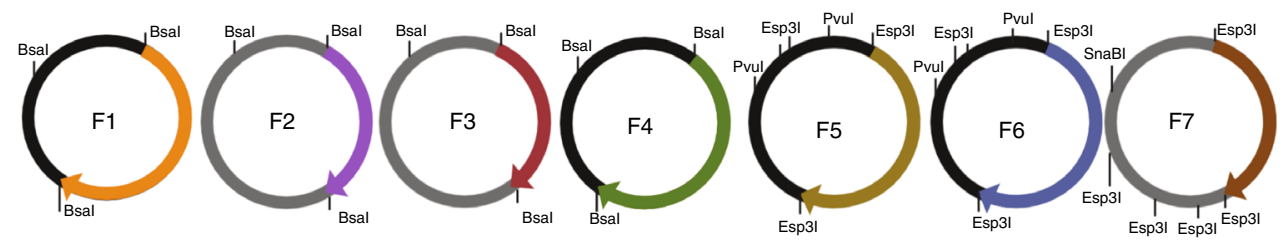

Stage 2: preparation of high-quality DNA fragments

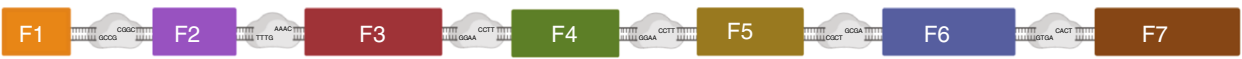

Stage 3: DNA ligation

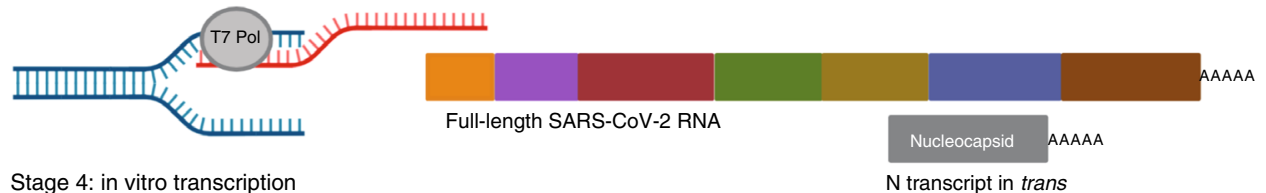

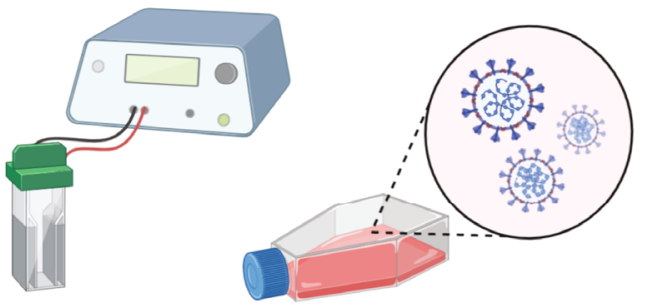

Stage 5: electroporation \& recovery of virus

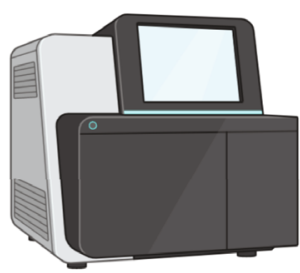

Stage 6: whole-genome sequencing

Fig. 1 | Overview of SARS-CoV-2 reverse genetic system. The SARS-CoV-2 infectious clone model contains seven cDNA fragments to cover the complete viral genome, to disrupt toxic elements, and to aid in genetic manipulation. The SARS-CoV-2 plasmids are amplified in E. coli and sequentially ligated following digestion with type II restriction enzymes to remove the plasmid backbone. The full-length viral DNA is then in vitro transcribed using T7 polymerase to generate full-length genomic SARS-CoV-2 RNA and electroporated into cells with N-protein transcript expressed in trans. Following electroporation, cells are seeded into cell culture flasks and virus recovered 2-5 d postelectroporation.

In response, our group developed a reverse genetic system that enables rapid synthesis of wild-type, mutant and reporter SARS-CoV-2 strains to study viral infection, transmission, pathogenesis, therapeutics and vaccines ${ }^{3}$. It applies the same principles from infectious clones developed for TGEV, MHV, SARS-CoV, Middle East respiratory syndrome (MERS)-CoV and several bat coronaviruses $^{5-7,12-15}$. Briefly, a contiguous panel of seven cDNA fragments was designed to span the entire genome of SARS-CoV-2 and were individually cloned into plasmids using type IIS restriction enzyme sites (Fig. 1). The type IIS restriction enzymes were chosen for cloning because they recognize asymmetric DNA sequences and generate unique cohesive overhangs that ensure one directional, seamless assembly of the seven DNA fragments into the genome-length cDNA. The assembled genome-length cDNA was used as a template for in vitro transcription. The resulting genome-length viral RNA was subsequently electroporated into cells to recover recombinant SARS-CoV-2. We originally described this method in our supporting Cell Host \& Microbe paper ${ }^{3}$, which showed that the full-genome cDNA was highly infectious after electroporation into cells. The infectious-clonederived SARS-CoV-2 (icSARS-CoV-2) exhibited similar plaque morphology, viral RNA profile and replication kinetics to a clinical isolate. In addition, we generated a stable mNeonGreen SARS-CoV-2 (icSARS-CoV-2-mNG), which was successfully used to evaluate the antiviral activities of interferon 
and vaccine development ${ }^{2,3,16-18}$. In this protocol article, we provide more detailed information for using this method, including troubleshooting information.

\section{Overview of the procedure}

Stage 1 of the procedure (Steps 1-33) is preparation of the seven plasmids that contain SARS-CoV-2 fragments F1-F7. The plasmids should be validated by restriction enzyme digestion and Sanger sequencing to exclude introduction of any undesired mutations into the plasmids prior to assembly of the full-length SARS-CoV-2 DNA. Stage 2 (Steps 34-45) involves the preparation of high-quality DNA fragments for downstream experiments by restriction enzyme digestion of the Maxiprep plasmids. Stage 3 (Steps 46-89) involves assembling the seven DNA fragments into a full-length SARS-CoV-2 DNA in vitro using a T4 DNA ligase. Two separate ligation steps increase the ligation efficiency of the full-length DNA and avoid nonspecific ligation between fragments F3 and F7. Afterward, the full-length ligation product is immediately purified by phenol-chloroform extraction and isopropanol precipitation. Stage 4 (Steps 90-96) is in vitro transcription of full-length RNA and $\mathrm{N}$ gene RNA. Stage 5 (Step 97) involves recovery of the SARS-CoV-2 recombinant virus from cell culture via RNA electroporation. Two different methods can be used for electroporation, using either Vero E6 cells only or BHK-21 and VeroE6 cells. Stage 6 (Steps 98-108) involves whole-genome Sanger sequencing of the virus to verify the entire viral genome sequence. The procedures of stages 1-4 can be performed in a general laboratory. The procedures of stages 5 and 6 that involve manipulating the SARS-CoV-2 must be done in a biosafety laboratory level 3 (BSL-3) facility.

\section{Alternative methods}

Our seven-cDNA-fragment approach has several key advantages over alternative methods, including bacterial artificial chromosomes, a vaccinia virus and yeast recombination-based assembly ${ }^{11,19}$. First, it permits rapid generation of mutant and reporter viruses by manipulation of a smaller plasmid (i.e., the plasmid that contains the targeted mutation fragment), reducing the risk of off-target mutations or deletions being inadvertently incorporated into the recombinant virus. Second, this approach allows simultaneous manipulation of multiple mutations from different cDNA fragments. More than one mutation from different cDNA fragments can be engineered in parallel to make combinatory mutant viruses. Such flexibility is important when characterizing a combinatory effect of multiple viral elements on host immune response or developing a live-attenuated vaccine platform, which often requires multiple mutation sites to be investigated at the same time ${ }^{20,21}$. In addition, the sevenfragment system allows quick insertion of mutations that arise from sequencing of new clinical isolates or swapping of regions from related coronaviruses found in animals ${ }^{13,22}$. Collectively, the reverse genetic system offers a wealth of opportunities to explore and study SARS-CoV-2 infection and pathogenesis.

Although the in vitro ligation approach allows rapid preparation of mutant and reporter viruses, the requirement to assemble and transcribe genome-length RNA requires technical expertise. Alternative coronavirus reverse genetic systems have used bacterial artificial chromosomes, a vaccinia virus and a yeast recombination-based assembly ${ }^{11,19}$. These alternative systems offer less assembly requirements, but are more prone to potential off-target mutations due to the use of larger size of viral cDNA and the need for amplification in host cells. Besides our SARS-CoV-2 infectious cDNA clone $^{3}$, a yeast-based platform and a similar multiple plasmid approach have been shown to produce recombinant SARS-CoV- $2^{19,23}$. The yeast platform required screening of several clones to identify virus equivalent to the original clinical isolate ${ }^{19}$. In contrast, both of the cDNA-fragment-based approaches yielded production of recombinant SARS-CoV-2 equivalent to the clinical isolate. These results are consistent with the previously characterized phenotypes of the epidemic SARS-CoV and MERS-CoV isolates as compared with their recombinant versions ${ }^{5,15}$. The fidelity to the clinical isolate of SARS-CoV-2 is an important advantage of these multiple plasmid infectious clone systems.

\section{Limitations and experimental design considerations}

Our experimental design is to clone seven cDNA fragments covering the entire genome of SARS$\mathrm{CoV}-2$ into plasmid vectors, resulting in seven plasmids. The seven viral cDNA fragments are engineered into plasmids based on the nucleotide sequences for type IIS restriction enzymes. The type IIS restriction enzymes were chosen because they recognize asymmetric DNA sequences and cleave outside of their recognition sequence, thus allowing directional assembly of multiple DNA fragments. There are two considerations for choosing the starting and ending nucleotide positions for each 

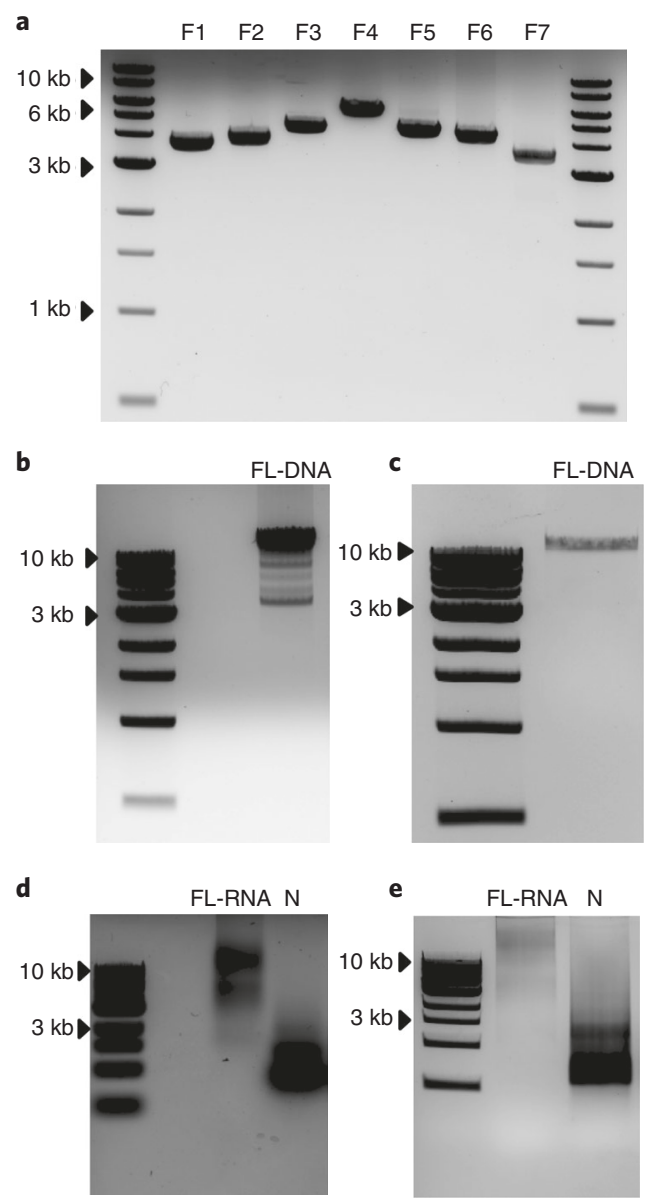

Fig. 2 | Gel extraction of SARS-CoV-2 fragments, full-length cDNA and full-length viral RNA. a, Agarose gel showing each SARS-CoV-2 DNA fragment (1 $\mu \mathrm{L}$ of each) isolated post-restriction enzyme digestion and utilized for in vitro ligation. b,c, Representative gels from successful (b) and unsuccessful (c) attempts to generate full-length SARS-CoV-2 cDNA. d,e, Representative agarose gels from successful (d) and unsuccessful (e) attempts to generate in vitro transcribed full-length SARS-CoV-2 viral RNA prior to electroporation and virus recovery.

cDNA fragment: (i) to divide the entire viral genome into seven fragments with reasonable DNA length for quick reverse-transcription polymerase chain reaction (RT-PCR) amplification and molecular cloning based on the BsaI and Esp3I restriction enzymes and (ii) to minimize the nonspecific ligation of the four-base overhangs generated by BsaI and Esp3I. This seven-plasmid approach allows simultaneous manipulation of different viral fragments of interest via standard molecular approaches (e.g., PCR or site-directed mutagenesis) to generate recombinant viruses with multiple changes.

Despite success across coronavirus platforms, several issues can potentially disrupt the efficacy of our reverse genetic system. We have found variability in the electroporation capacity of Vero E6 cell lineages. Although the electroporation buffer improves the efficiency in Vero E6 cells, we also include an alternative approach utilizing BHK-21 cells, a Golden Syrian hamster fibroblast cell line that can be used for virus generation in other $\mathrm{CoV}$ systems $\mathrm{s}^{6,7}$. BHK-21 cells are not suitable for continued SARS-CoV-2 replication due to a lack of angiotensin-converting enzyme 2 (ACE2) receptor expression; however, these cells tolerate electroporation well and allow sufficient SARS-CoV-2 production to seed cocultured Vero E6 cells. Overall, electroporation efficiency is low in both BHK-21 and Vero E6 cells $(<1 \%$ cells based on the mNeonGreen expression from cells electroporated with mNeonGreen-containing SARS-CoV-2 RNA) and coculture with non-electroporated Vero E6 cells can improve viral yield for passage 0 . Notably, we find that viral yields improve with the subsequent passage and these stocks are generally used for experiments.

Another key barrier to success with our reverse genetic system is deletions and mutations while propagating the cDNA plasmids. Despite their smaller size and our efforts to disrupt toxic elements, the SARS-CoV-2 plasmids are still prone to errors and deletions when amplified in Escherichia coli. 
To reduce incorporation of these errors, we sequence to verify cDNA plasmids at each stage of amplification. To prevent continued mutations/deletions in certain SARS-CoV-2 plasmids, we also include instructions for alternative growth conditions with lower temperatures $\left(25\right.$ or $30{ }^{\circ} \mathrm{C}$ ) for longer times (up to $48 \mathrm{~h}$ ) to facilitate generation of cDNA with fidelity to the original viral sequence.

In addition, we use a Dark Reader blue transilluminator for manipulation of SARS-CoV-2 plasmid DNA. We found that use of standard ultraviolet (UV) light boxes yields sequence mutations and poor virus recovery. We also note that each plasmid has prescribed competent cells (Top10 or EPI300), which are associated with lower mutation and deletion frequencies as well as improved plasmid yields. Overall, this reverse genetic system requires significant effort to prevent mutations/deletions from disrupting SARS-CoV-2 generation.

The conditions for assembly, ligation and electroporation of the viral nucleic acid must be carefully considered when using this reverse genetic system. A key challenge is the requirement for a sufficient concentration of cDNA fragments for ligation. We have included calculations for the necessary amount of each fragment, as well as a visual image of the cDNA fragments (after gel purifications) to provide a reference for the amount of plasmid DNA needed for successful in vitro assembly of fulllength cDNA (Fig. 2a). We also include alternative growth conditions (larger cultures and longer culture time) to amplify low-yield plasmids if necessary. In general, we find it necessary to complete a maxiprep (Qiagen) for each plasmid to have sufficient DNA concentrations to facilitate full-length cDNA assembly.

We include gel images of full-length SARS-CoV-2 DNA after ligation and full-length RNA after in vitro transcription to show the amount required for effective versus ineffective electroporation and virus recovery (Fig. 2b-d). For poor full-length DNA yields, we offer alternative ligation conditions as well. Together, these tips and data should provide critical references for use and manipulation of the SARS-CoV-2 infectious clone.

\section{Materials}

\section{Cells}

- EPI300 competent cells (Lucigen, cat. no. C300C105)

- One Shot TOP10 chemically competent cells (Thermo Fisher Scientific, cat. no. C404010)

- BHK-21 cells (RRID: CVCL_1915; cat. no. ATCC CCL-10)

- Vero E6 cells (lab-passaged derivative of ATCC CRL-1586; RRID: CVCL_0574) !CAUTION Periodically make sure the mammalian cells used are authentic and are not contaminated with mycoplasma.

\section{Reagents}

- $0.25 \%$ trypsin-ethylenediaminetetraacetic acid (EDTA) $(1 \times)$ (Thermo Fisher Scientific, cat. no. 25200-072)

- 0.4\% (wt/vol) Trypan blue (Thermo Fisher Scientific, cat. no.15250-061)

- 1 kb DNA ladder (NEB, cat. no. N3232L)

- 10× Cutsmart buffer (NEB, cat. no. B7204S)

- Absolute ethanol (EtOH; anhydrous, 200 proof/100\% (vol/vol); VWR, cat. no. 89125-170)

- Acid phenol:chloroform (pH 4.5; Ambion, cat. no. AM9722)

- Agarose (Bio-Rad, cat. no.1613102)

- Ampicillin sodium salt (Sigma-Aldrich, cat. no. A9518)

- Chloramphenicol (Sigma-Aldrich, cat. no. 0378)

- CopyControl induction solution (Lucigen, cat. no. CCIS125)

- Dulbecco's modified Eagle's medium (DMEM), high glucose (Life Technologies, cat. no. 11965-092)

- DNA loading buffer (NEB, cat. no. B7024S)

- EDTA (Sigma-Aldrich, cat. no. 324503)

- Electroporation buffer (Mirus, cat. no. MIR 50117)

- Ethidium bromide (EB; $10 \mathrm{mg} \mathrm{mL}^{-1}$; Bio-Rad, cat. no. 161-0433)

- Fetal bovine serum (FBS) (Hyclone, cat. no. SH3007103HI)

- Glycerol ( $\geq 99.5 \%$ (wt/vol); Sigma-Aldrich, cat. no. G9012)

- Hydrogen chloride (HCl; 36.5-38\%; Sigma-Aldrich, cat. no. H1758-500ML)

- illustra MicroSpin G-25 columns (GE Healthcare, cat. no. 27-5325-01)

- Isopropanol (Sigma-Aldrich, cat. no. I9516)

- Luria-Bertani (LB) agar (ready-made powder; Thermo Fisher Scientific, cat. no. DF0401-17) 
- LB broth (ready-made powder; Thermo Fisher Scientific, cat. no. DF0402-08-0)

- mMESSAGE mMACHINE T7 transcription kit (Thermo Fisher Scientific, cat. no. AM1344)

- Phosphate-buffered saline (PBS) (Thermo Fisher Scientific, cat. no. 10010023)

- Penicillin/streptomycin (Thermo Fisher Scientific, cat. no.15140-122)

- Phenol:chloroform:isoamyl alcohol 25:24:1 (pH 8.05; Invitrogen, cat. no. 15593-031)

- Platinum SuperFi II DNA polymerase (Thermo Fisher Scientific, cat. no. 12361010)

- QIAGEN plasmid maxi kit (Qiagen, cat. no. 12163)

- QIAprep spin Miniprep kit (Qiagen, cat. no. 27106)

- QIAquick gel extraction kit (Qiagen, cat. no. 28706)

- QIAquick PCR purification kit (Qiagen, cat. no. 28106)

- Restriction enzyme BsaI-HFv2 (NEB, cat. no. R3733)

- Restriction enzyme Esp3I (NEB, cat. no. R0734L)

- Restriction enzyme PvuI-HF (NEB, cat. no. R3150S)

- Restriction enzyme SnaBI (NEB, cat. no. R0130L)

- Ribonucleotide solution mix (rNTP solution mix; NEB, cat. no. N0466L)

- SOC outgrowth medium (10 mL; Invitrogen, cat. no. 15544034)

- Sodium acetate (Sigma-Aldrich, cat. no. S8750)

- Sodium hydroxide pellets ( $\mathrm{NaOH}$; Sigma-Aldrich, cat. no. S8045)

- SuperScript first-strand synthesis system (Thermo Fisher Scientific, cat. no. 18091050)

- T4 ligase and ligation buffer (NEB, cat. no. M0202L)

- Tris-base (Sigma-Aldrich, cat. no. T1503)

- TRIzol LS reagent (Thermo Fisher Scientific, cat. no. 10296028)

- UltraPure DNase/RNase-free distilled water (Thermo Fisher Scientific, cat. no. 10977015)

\section{Equipment}

-1-L glass bottle (Duran, cat. no. 21820545)

-2-mL screw-top tube (VWR, cat. no. 101093-752)

- 250-mL glass bottle (Duran, cat. no. 21801365)

-4-mm cuvettes (Bio-Rad, cat. no. 1652088)

- 90-mm Petri dishes (Thermo Fisher Scientific, cat. no. 263991)

- Automated cell counter (Bio-Rad, cat. no. 1450102)

- C-fold paper towel (Scott)

- $\mathrm{CO}_{2}$ incubator (NuAire)

- Cooler (Coleman)

- Counting slide (Bio-Rad, cat. no. 145-0011)

- Dark Reader transilluminators (DR89X model, Clare Chemical Research)

- Eppendorf benchtop centrifuge (models 5810R, 5424R, 5425)

- Erlenmeyer flask, 1 L (Pyrex, cat. no. 4446-1L)

- Erlenmeyer flask, 250 mL (Pyrex, cat. no. 4446-250)

- Falcon 15-mL conical tube (Corning, cat. no. 352096)

- Falcon 50-mL conical tube (Corning, cat. no. 352070)

- Fisherbrand Isotemp stirrer (Thermo Fisher Scientific)

- Gel DOC EZ system (Bio-Rad, cat. no. 170827)

- Gene Pulser Xcell electroporation systems (Bio-Rad, cat. no. 1652660)

- Horizontal electrophoresis systems (Bio-Rad)

- Incubator for bacteria culture (Thermo Fisher Scientific)

- L-shaped cell spread (Thermo Fisher Scientific, cat. no. 14-665-230)

- Microcentrifuge tube, $1.7 \mathrm{~mL}$ (Axygen, cat. no. MCT-175-C)

- Microwave (Oster)

- Milli-Q ultrapure water systems

- New Brunswick Scientific Innova 43R incubator shakers (Eppendorf, cat. no. M1320-0000)

- PCR tube, $0.2 \mathrm{~mL}$ (Axygen, cat. no. PCR-02-C)

- $\mathrm{pH}$ meter (Sartorius)

- Research Plus pipettes (0.1-2.5, 0.5-10, 2-20, 1-100, 20-200 and 100-1,000 $\mu \mathrm{L}$; Eppendorf)

- Secura balance (Sartorius, cat. no. ENTRIS 6202-1S)

- S1 pipet fillers (Thermo Fisher Scientific, cat. no. 9501)

- Spectrophotometer (DS-11 series, DENOVIX) 
- T175 flask (Corning, cat. no. 431080)

- T-75 flask (Corning, cat. no. 430641U)

- Thermocycler (models C1000 Touch and T100, Bio-Rad)

- VACUBOY (INTEGRA Biosciences)

- Vortex (Thermo Fisher Scientific)

- Water bath (Thermo Fisher Scientific)

\section{Reagent setup}

$\mathbf{0 . 8 \%}$ agarose gel

Weigh $0.8 \mathrm{~g}$ agarose powder in a $250-\mathrm{mL}$ conical flask and add $100 \mathrm{~mL} 1 \times$ Tris-acetate-EDTA (TAE) buffer. Swirl the conical flask to blend the contents, and cover the top of the conical flask with plastic wrap to reduce evaporation. Microwave for 1-2 min to melt the agarose completely but do not overboil. Cool down the agarose solution to $50-60{ }^{\circ} \mathrm{C}$ and pour it into a gel dock slowly to avoid bubble formation. Add EB to the agarose solution to final concentration of $0.5 \mu \mathrm{g} \mathrm{mL} \mathrm{L}^{-1}$, distribute the EB evenly by shaking the gel dock gently and quickly insert a gel comb into the gel dock. The agarose gel will be ready to use once it solidifies.

\section{Ampicillin stock $\left(100 \mathrm{mg} \mathrm{mL} \mathrm{m}^{-1}\right)$}

Weigh out $10 \mathrm{~g}$ ampicillin sodium salt in a clean $250-\mathrm{mL}$ glass bottle. Add $100 \mathrm{~mL}$ UltraPure deionized water and stir thoroughly until components are completely dissolved. Sterilize the ampicillin solution by passing through a $0.22-\mu \mathrm{m}$ filter, and aliquot into sterile $1.7-\mathrm{mL}$ tubes $(1 \mathrm{~mL}$ per tube) to avoid multiple freeze-thaws. Ampicillin aliquots may be stored at $-20{ }^{\circ} \mathrm{C}$ for at least 1 year. For frequent use, store the ampicillin stock at $4{ }^{\circ} \mathrm{C}$ for no more than 1 month.

\section{Cell culture media}

Prepare all the cell culture medium in a biosafety cabinet. To make $10 \%$ or $2 \%$ FBS medium, add 55 or $10 \mathrm{~mL}$ FBS into $500 \mathrm{~mL}$ high-glucose DMEM supplemented with $1 \%$ penicillin/streptomycin solution, respectively. Use 10\% FBS culture medium for cell propagation and 2\% FBS culture medium for virus infection and propagation.

\section{Chloramphenicol stock $\left(25 \mathrm{mg} \mathrm{mL}{ }^{-1}\right)$}

Add $2.5 \mathrm{~g}$ chloramphenicol into $100 \mathrm{~mL}$ absolute ethanol and vortex vigorously to ensure all the chloramphenicol powder is fully dissolved. Filter sterilization is not necessary since it is in $100 \%$ ethanol. Dispense the chloramphenicol stock solution into aliquots (500 $\mu \mathrm{L}$ in $1.7-\mathrm{mL}$ tube). Chloramphenicol aliquots may be kept in a $-20{ }^{\circ} \mathrm{C}$ freezer for at least 1 year. ! CAUTION Ethanol is flammable. Keep ethanol and dissolved chloramphenicol stocks away from fire.

\section{EDTA, 0.5 M, pH 8.0}

Add $148 \mathrm{~g}$ EDTA into $1 \mathrm{~L}$ UltraPure deionized water and mix thoroughly on a magnetic stirrer. To improve EDTA solubility in water, adjust $\mathrm{pH}$ to 8.0 by adding $\mathrm{NaOH}(\sim 30-40 \mathrm{~g})$ into the solution gradually. Keep stirring until all the components are fully dissolved and sterilize EDTA solution by autoclaving at $121^{\circ} \mathrm{C}$ for $30 \mathrm{~min}$. The EDTA solution is stable at room temperature $\left(20-30^{\circ} \mathrm{C}\right)$ for up to 1 year.

\section{$70 \%$ ethanol}

Mix $15 \mathrm{~mL}$ nuclease-free water with $35 \mathrm{~mL}$ absolute ethanol in a 50-mL Falcon tube and keep at $-20{ }^{\circ} \mathrm{C}$ for long-term storage. ! CAUTION $70 \%$ ethanol is still flammable. Keep stocks away from fire.

\section{$\mathbf{5 0 \%}$ glycerol buffer}

Combine $50 \mathrm{~mL}$ glycerol with $50 \mathrm{~mL}$ UltraPure deionized water in a $250-\mathrm{mL}$ glass bottle and shake up the solution. Autoclave the solution at $121{ }^{\circ} \mathrm{C}$ for $20 \mathrm{~min}$ and place in a $4{ }^{\circ} \mathrm{C}$ freezer for storage. ! CAUTION Keep and store the 50\% glycerol buffer in a sterile environment.

\section{LB agar plates containing ampicillin or chloramphenicol}

Add $28 \mathrm{~g} \mathrm{LB}$ agar powder to $800 \mathrm{~mL}$ UltraPure deionized water in a 1-L glass bottle and swirl to mix. Autoclave to sterilize at $121.0^{\circ} \mathrm{C}$ for $30 \mathrm{~min}$, and the components will be dissolved after autoclaving. Cool down the LB agar solution to $55{ }^{\circ} \mathrm{C}$ before adding ampicillin (to final concentration of 
Table 1 | Restriction enzymes for validation of seven SARS-CoV-2 plasmids

Plasmid Restriction enzyme(s) DNA fragments with expected size

\begin{tabular}{|c|c|c|}
\hline pUC57-CoV-2-F1 & Bsal & $\mathbf{3 , 6 4 4} \mathbf{b p}(\mathbf{F} \mathbf{1})^{a}+1,367 \mathrm{bp}+1,366 \mathrm{bp}$ \\
\hline pCC1-CoV-2-F2 & Bsal & $6,466 b p+\mathbf{3 , 8 8 6}$ bp (F2) ${ }^{a}+1,344 b p$ \\
\hline pCC1-CoV-2-F3 & Bsal & $6,466 b p+\mathbf{4 , 4 8 0}$ bp (F3) ${ }^{a}+1,344 b p$ \\
\hline pUC57-CoV-2-F4 & Bsal & $\mathbf{5 , 6 0 7}$ bp (F4) $\mathbf{~}^{a}+1,367 b p+1,366$ bp \\
\hline pUC57-CoV-2-F5 & Esp3I and Pvul & $\mathbf{4 , 4 5 7} \mathbf{b p}(\mathbf{F 5})^{a}+1,674 b p+620 b p+234 b p+161 b p+42 b p$ \\
\hline pUC57-CoV-2-F6 & Esp3I and Pvul & $\mathbf{4 , 2 8 4} \mathbf{b p}(\mathbf{F} \mathbf{6})^{a}+1,674 b p+620 b p+234 b p+161 b p+42 b p$ \\
\hline pCC1-CoV-2-F7 & Esp3I and SnaBI & $\begin{array}{l}\mathbf{3 , 5 6 3} \mathbf{b p}(\mathbf{F 7})^{a}+2,522 b p+2,395 b p+1,689 b p+651 b p \\
+553 b p\end{array}$ \\
\hline
\end{tabular}

${ }^{\mathrm{a}}$ Fragment of SARS-CoV-2 genome.

$100 \mu \mathrm{g} \mathrm{mL}^{-1}$ ) or chloramphenicol (to final concentration of $12.5 \mu \mathrm{g} \mathrm{mL}{ }^{-1}$ ). In a sterile bench area, pour LB agar solution ( $20 \mathrm{~mL}$ per dish) into a $90-\mathrm{mm}$ Petri dish. Usually, $800 \mathrm{~mL}$ LB agar solution is sufficient for casting 20-30 agar plates. Return the lids to the plates, and cool the plates down at room temperature until the agar solidifies. Agar plates containing antibiotics can be stored in plastic bags or sealed with Parafilm at $4{ }^{\circ} \mathrm{C}$ in the dark for up to 3 months. ! CAUTION Keep the chloramphenicol stocks away from fire.

\section{LB medium solution}

Dissolve $20 \mathrm{~g} \mathrm{LB}$ powder into $1 \mathrm{~L}$ UltraPure deionized water and autoclave at $121{ }^{\circ} \mathrm{C}$ for $30 \mathrm{~min}$ for sterilization. After autoclaving, the LB medium solution can be stored at room temperature for up to 4 months.

To prepare the LB medium containing ampicillin or chloramphenicol for the bacteria selection, add $0.8 \mathrm{~mL}$ ampicillin stock $\left(80 \mathrm{mg} \mathrm{mL}^{-1}\right)$ or $500 \mu \mathrm{L}$ chloramphenicol stock $\left(25 \mathrm{mg} \mathrm{mL}^{-1}\right)$ into $1 \mathrm{~L}$ LB medium respectively in a sterilized environment. The final working concentrations are $100 \mu \mathrm{g}$ $\mathrm{mL}^{-1}$ for ampicillin and $12.5 \mu \mathrm{g} \mathrm{mL}{ }^{-1}$ for chloramphenicol. Store the $\mathrm{LB}$ medium containing antibiotics at $4{ }^{\circ} \mathrm{C}$ in the dark. ! CAUTION Antibiotics degrade over time, so LB medium containing antibiotics should be made up fresh or frequently.

\section{Sodium acetate (3.0 M, pH 5.2)}

Dissolve $246.1 \mathrm{~g}$ sodium acetate in $500 \mathrm{~mL}$ deionized water. Adjust the $\mathrm{pH}$ to 5.2 using glacial acetic acid. Allow the solution to cool overnight. Adjust the $\mathrm{pH}$ once more to 5.2 with glacial acetic acid. Adjust the final volume to $1 \mathrm{~L}$ using deionized water and filter-sterilize.

\section{0× TAE buffer}

Weigh out $484 \mathrm{mg}$ Tris-base in a clean 2-L glass bottle and add 1,500 mL UltraPure deionized water. After the Tris-base has dissolved, carefully pour $114.2 \mathrm{~mL}$ glacial acetic acid and $200 \mathrm{~mL} 0.5 \mathrm{M}$ EDTA ( $\mathrm{pH}$ 8.0) into the solution and mix them up by agitating. Top up the TAE solution to final volume of $2 \mathrm{~L}$ with water and store the $50 \times$ TAE buffer at room temperature.

To prepare $1 \times$ TAE buffer ( $40 \mathrm{mM}$ Tris, $20 \mathrm{mM}$ acetate and $1 \mathrm{mM}$ EDTA), which is used for DNA electrophoresis, dilute $400 \mathrm{~mL} 50 \times$ TAE buffer into $19.6 \mathrm{~L}$ UltraPure deionized water.

\section{Plasmids}

We have successfully cloned seven different DNA fragments spanning the entire genome of SARSCoV-2 into commercial pUC57 (GenScript, Piscataway, NJ) or pCC1 (Epicenter Biotechnologies, Madison, WI) vectors, resulting in seven plasmids: pUC57-CoV-2-F1, pCC1-CoV-2-F2, pCC1-CoV2-F3, pUC57-CoV-2-F4, pUC57-CoV-2-F5, pUC57-CoV-2-F6 and pCC1-CoV-2-F7. The sequences of the seven plasmids are included in Supplementary Fig. 1. Type IIS restriction enzymes BsaI and Esp3I, which recognize asymmetric DNA sequences and cleave outside of their recognition sequence, have been widely used for Golden Gate assembly to ensure directional assembly of multiple DNA fragments simultaneously. Additional restriction enzymes (such as PvuI and SnaBI) are used to efficiently resolve the desired DNA fragments from other byproducts in the same restriction reactions during electrophoresis. Table 1 outlines the restriction enzyme cleavage sites in the seven plasmids that would be used for preparing the fragments prior to ligation in this protocol. The seven plasmids 
can be used as templates for generating mutations of interest via standard molecular approaches, such as PCR or site-directed mutagenesis.

pUC57

pUC57 is a high-copy-number (500-700 copies per cell) plasmid that contains an ampicillin-resistant gene. It can be propagated in E. coli to produce a high yield of plasmids for downstream use. pUC57CoV-2-F1, pUC57-CoV-2-F4, pUC57-CoV-2-F5 and pUC57-CoV-2-F6 are stable when they are propagated in the commercially available Top10 competent cells. Several attempts to clone the F2, F3 and F7 fragments into the pUC57 vector that can propagate in the Top10 competent cells failed, probably due to the toxicity of these fragments to the bacterial cells. Finally, F2, F3 and F7 were successfully cloned in pCC1 vector and propagated stably in EPI300 competent cells. $\triangle$ CRITICAL Top10 competent cells are recommended. Other cells must be verified for plasmid compatibility/stability prior to preparing large batches of those plasmids.

\section{pCC1}

pCC1 is a bacmid cloning vector with a controlled copy number. It is ideal for amplifying large, unstable and bacteria-toxic DNA fragments in E. coli. Before induction, the copy number of pCC1 plasmid is one copy per cell. Upon induction by L-arabinose, the copy number of pCC1can be 10-20 copies per cell in the bacteria cells (EPI300 competent cells are recommended for propagating the pCC1-derived plasmids).

\section{Equipment setup}

\section{Electroporator setup}

This protocol is based on the use of Gene Pulser Xcell electroporation systems using the exponential decay pulse for electroporating RNAs into mammalian cells. We optimized the parameter settings including voltages, capacitance and pulse times for different cells. The conditions used in this study give us high and reproducible transformation efficiency with high viability of cells after electroporation. The parameter settings for electroporation of Vero cells are indicated below: voltage, $270 \mathrm{~V}$; capacitance, $950 \mu \mathrm{F}$; resistance, $\infty$; cuvette size $(\mathrm{mm})$ : 4 . One pulse is needed for electroporation of Vero cells. The parameter settings for electroporation of BHK-21 cells are: voltage, $850 \mathrm{~V}$; capacitance, $25 \mu \mathrm{F}$; resistance, $\infty$; cuvette size $(\mathrm{mm})$ : 4. Three pulses with 3 -s intervals between each pulse are needed for electroporation of BHK-21 cells. Alternative electroporation systems (such as 4D-Nucleofector X unit) with optimized settings can also be used.

Stage 1: Propagation of plasmids containing SARS-CoV-2 fragments Timing $3.5 \mathrm{~d}$ Chemical transformation Timing $\mathbf{2} \mathbf{h}$

$\triangle$ CRITICAL STEP The transformation should be performed in a sterile environment to prevent contamination.

1 Before transformation, complete the following steps:

- Quantify the concentration of each plasmid using a spectrophotometer

- Warm a water bath to $42{ }^{\circ} \mathrm{C}$

- Disinfect the bench surface with $70 \%$ ethanol

- Light a Bunsen burner to provide a sterile environment for transformation

$\triangle$ CRITICAL STEP The water bath should be regularly calibrated for accurate temperature. Inappropriate temperature would decrease transformation efficiencies.

2 Thaw appropriate chemically competent cells on ice. Add 1-10 ng of plasmids to the thawed cells and mix by tapping the tube or swirling gently.

- For pUC57-derived plasmids, including pUC57-CoV-2-F1, pUC57-CoV-2-F4, pUC57-CoV-2-F5 and pUC57-CoV-2-F6, use Top10 competent cells for transformation.

- For pCC1-derived plasmids, including pCC1-CoV-2-F2, pCC1-CoV-2-F3 and pCC1-CoV-2-F7, use EPI300 competent cells for transformation.

$\triangle$ CRITICAL STEP Competent cells are sensitive to temperature and salt/buffer conditions. Add the DNA solution at a volume $<10 \%$ of the competent cell suspension. Keep the competent cells on ice prior to heat shock. The thawed competent cells should not be refrozen at $-80^{\circ} \mathrm{C}$.

3 After adding the plasmids, immerse the tube immediately into ice. Incubate the plasmid-cell mixtures for 20-30 min on ice. 
4 Incubate the tube containing the plasmid-cell mixtures in a $42{ }^{\circ} \mathrm{C}$ water bath for $30 \mathrm{~s}$.

5 Immediately put the tube back on ice and incubate for $2 \mathrm{~min}$.

6 Add $250 \mu \mathrm{L}$ SOC medium (prewarmed at room temperature) into the tube containing transformed cells.

7 Shake the cultures in a $37^{\circ} \mathrm{C}$ incubator at 230 r.p.m. for $60 \mathrm{~min}$ to recover the cells.

8 During the incubation period, warm LB agar plates supplemented with $100 \mu \mathrm{g} \mathrm{mL}^{-1}$ ampicillin (for pUC57-derived plasmids) or $12.5 \mu \mathrm{g} \mathrm{mL}{ }^{-1}$ chloramphenicol (for pCC1-derived plasmids) in a $37^{\circ} \mathrm{C}$ incubator.

9 After the $60 \mathrm{~min}$ incubation, inoculate $50 \mu \mathrm{L}$ of the cultures onto a prewarmed LB agar plate supplied with the appropriate antibiotics, and spread the cultures over the plate using L-shaped cell spreaders.

10 Place the plates upright in a $37^{\circ} \mathrm{C}$ incubator for $30 \mathrm{~min}$ to allow the cultures to be fully absorbed. Afterward, invert the plates and incubate at $37^{\circ} \mathrm{C}$ overnight $(16-20 \mathrm{~h})$.

? TROUBLESHOOTING

\section{Colony screen Timing 1 d or overnight}

11 After overnight incubation, pick up several well-separated colonies using sterile P10 tips and inoculate the colonies into LB broth containing proper antibiotics.

- For pUC57 vector-derived plasmids, inoculate the colonies into a 50-mL conical tube containing

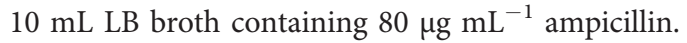

- For pCC1 vector-derived plasmids, inoculate the colonies into a 50-mL conical tube containing $10 \mathrm{~mL} \mathrm{LB}$ broth containing $12.5 \mu \mathrm{g} \mathrm{mL}^{-1}$ chloramphenicol.

$\triangle$ CRITICAL STEP The colonies may vary in size due to potential cryptical foreign gene expression from viral genome, which is usually toxic to the E. coli. Pick up four to six small/ medium-sized colonies per plasmid for validation.

DAUSE POINT Store the LB agar plates at $4{ }^{\circ} \mathrm{C}$ in the dark for future use (for up to 1 month).

12 Incubate the bacterial cultures at $37^{\circ} \mathrm{C}$ with shaking at 230 r.p.m. overnight $(12-16 \mathrm{~h})$.

$\triangle$ CRITICAL STEP Grow the bacterial cultures in tubes with volumes of more than three times that of the culture volume. The tubes should not be fully sealed to ensure enough air exchange. Do not extend the incubation time as more 'toxin' accumulates over time.

13 The next day, prior to Miniprep, save a bacteria glycerol stock for each colony by mixing $0.5 \mathrm{~mL}$ overnight culture with $0.5 \mathrm{~mL} 50 \%$ glycerol in a sterile $1.7-\mathrm{mL}$ Eppendorf tube. Store the glycerol stock in $-80{ }^{\circ} \mathrm{C}$ freezer for future use (stock should be stable for years). For pUC57-derived plasmids, the remaining overnight cultures are now ready for Miniprep, so you can skip Step 14 and proceed to Step 15. For pCC1-derived plasmids, an extra induction step (Step 14) is needed.

14 (Optional) For pCC1-derived plasmids only, inoculate $1.5 \mathrm{~mL}$ of overnight cultures into a new $50-\mathrm{mL}$ conical tube containing $13.5 \mathrm{~mL}$ LB broth supplemented with $12.5 \mu \mathrm{g} \mathrm{mL} \mathrm{m}^{-1}$ chloramphenicol and $15 \mu \mathrm{L}$ induction solution (supplemented by the manufacturer).

15 Shake the culture at $37^{\circ} \mathrm{C}$ and 230 r.p.m. for $5 \mathrm{~h}$, then use the induced cultures for Miniprep. $\triangle$ CRITICAL STEP The induction time should not exceed $5 \mathrm{~h}$. Longer culture time may increase the risk of mutation/deletion in the DNA fragments of the SARS-CoV-2.

\section{Plasmid Miniprep Timing 1-2 h}

16 Harvest the bacterial culture by centrifuging at 3,900 r.p.m. for $10 \mathrm{~min}$ at $16^{\circ} \mathrm{C}$ in a benchtop centrifuge (Eppendorf model 5810R).

17 Dispense the medium into a waste container containing $20 \%$ bleach. Invert the tubes and put them on absorbent papers to remove the residual liquid.

18 Save the bacterial pellets to extract plasmids using a Qiagen Miniprep kit by following the manufacturer's instructions.

PAUSE POINT The pellets can be either used immediately for Miniprep or preserved at $-20{ }^{\circ} \mathrm{C}$ until use.

19 At the final step of Miniprep, add $50 \mu \mathrm{L}$ nuclease-free water (prewarmed at $56^{\circ} \mathrm{C}$ ) into the Miniprep columns. Centrifuge at $>12,000 \mathrm{~g}$ for $2 \mathrm{~min}$ at room temperature to elute the plasmids.

20 Measure the yield and quality of the plasmids using a spectrophotometer.

DAUSE POINT The eluted plasmids can be either used immediately or stored at $-20{ }^{\circ} \mathrm{C}$ for up to at least 1 year until use. 


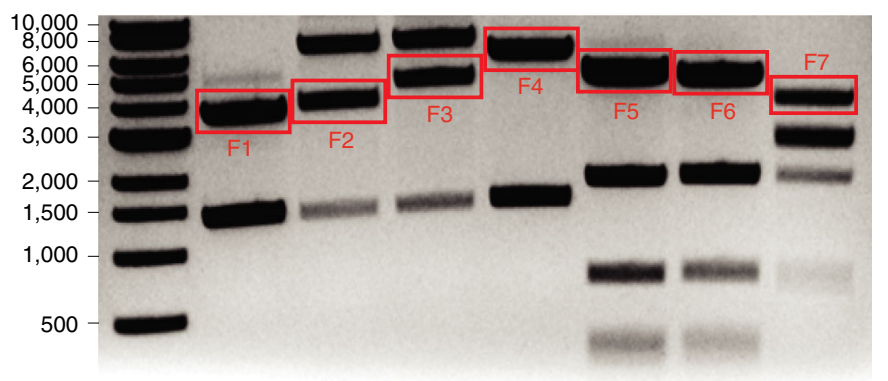

Fig. 3 | Representative gel images post-restriction enzyme digestion. The DNA ladders (bp) are indicated. The corresponding fragments of SARS-CoV-2 restricted from the plasmids are outlined.

\section{Plasmid validation by restriction enzyme digestion Timing $\mathbf{2} \mathrm{h}$}

$\triangle$ CRITICAL The plasmids prepared above are digested with appropriate restriction enzymes. The restriction enzymes used to validate the seven SARS-CoV-2 plasmids and the expected DNA fragments after restriction are indicated in Table 1.

21 Set up a $10-\mu \mathrm{L}$ digestion reaction system for each plasmid in a $0.2-\mathrm{mL}$ PCR tube. The setups are indicated in the table below.

Reaction systems for plasmid validation

\begin{tabular}{ll} 
Component & Volume $(\mu \mathrm{L})$ \\
\hline Nuclease-free water & Up to 10 \\
$10 \times$ Cutsmart buffer & 1 \\
Restriction enzymes & $0.5-1^{a}$ \\
DNA plasmid & TBD $(200-300 \mathrm{ng})$ \\
& \\
\hline a Overall volume of the enzyme should be $<10 \%$ of the total reaction volume &
\end{tabular}

22 Incubate the reaction at $37^{\circ} \mathrm{C}$ for $1 \mathrm{~h}$. During the incubation period, cast a $0.6 \%$ agarose gel containing EB with 1-mm-wide well for DNA electrophoresis.

! CAUTION EB is a mutagen. Wear proper personal protective equipment (PPE) when handling EB-containing solutions and gels.

23 After $1 \mathrm{~h}$ of incubation, reactions are stopped by adding $2 \mu \mathrm{L} 6 \times$ DNA loading buffer. Load the samples onto a $0.8 \%$ agarose gel using a P10 pipette. Pipet $5 \mu \mathrm{L} 1-\mathrm{kb}$ DNA ladder into an independent well of the same gel.

24 Resolve the DNA fragments by electrophoresis at $120 \mathrm{~V}$ for $25 \mathrm{~min}$ in $1 \times$ TAE buffer.

25 Acquire images of the gel using a Gel DOC-EZ imager. Evaluate the results for each plasmid, referring to Table 1 for expected fragment sizes. Figure 3 shows an example of the rection digestion results. For each plasmid, one validated colony is sufficient for proceeding to the next step.

\section{? TROUBLESHOOTING}

\section{Plasmid Maxiprep Timing $24 \mathrm{~h}$}

$\triangle$ CRITICAL The glycerol stocks of validated plasmids are used for preparing large batches of plasmids.

26 Inoculate $0.1 \mathrm{~mL}$ glycerol stock into a $250-\mathrm{mL}$ Erlenmeyer flask containing $50 \mathrm{~mL} \mathrm{LB}$ medium supplemented with appropriate selective antibiotics.

27 Shake the cultures in a $37{ }^{\circ} \mathrm{C}$ incubator at 230 r.p.m. overnight (12-16 h).For pUC57-derived plasmids, the overnight cultures are ready for Maxiprep (50 $\mathrm{mL}$ should be sufficient), so you can skip Step 27 and proceed to Step 28.

28 (Optional) For pCC1-derived plasmids only, transfer $50 \mathrm{~mL}$ of the overnight cultures into a 2-L Erlenmeyer flask containing $450 \mathrm{~mL}$ fresh $\mathrm{LB}$ broth supplemented with $12.5 \mu \mathrm{g} \mathrm{mL} \mathrm{L}^{-1}$ chloramphenicol and $500 \mu \mathrm{L}$ induction solution. Incubate the culture at $37{ }^{\circ} \mathrm{C}$ with shaking at 230 r.p.m. for 5 h. The new cultures are used for Maxiprep.

$\triangle$ CRITICAL STEP The induction time should not exceed $5 \mathrm{~h}$. Longer culture time may increase the risk of mutation/deletion in the DNA fragments of the SARS-CoV-2.

29 Pellet down the cultures by spinning at 7,000 r.p.m. for $5 \mathrm{~min}$. 
30 Save the pellets for plasmid extraction using QIAGEN plasmid plus MAXI kit according to the manufacturer's instructions.

DAUSE POINT The pellets can be either used immediately or preserved at $-20{ }^{\circ} \mathrm{C}$ for several weeks until use.

31 At the last step of Maxiprep, add $100-200 \mu \mathrm{L}$ nuclease-free water (prewarmed at $56^{\circ} \mathrm{C}$ ) into the columns.

32 Incubate at room temperature or $56{ }^{\circ} \mathrm{C}$ incubator for $2 \mathrm{~min}$.

33 Elute the plasmids by centrifuging at >12,000 r.p.m. for $2 \mathrm{~min}$ at room temperature.

34 Determine the yield and quality of plasmids using a spectrophotometer. Note that the yields of plasmids may vary from 100 to $300 \mu \mathrm{g}$.

PAUSE POINT The eluted plasmids can be either used immediately or preserved at $-20{ }^{\circ} \mathrm{C}$ until use.

\section{? TROUBLESHOOTING}

Stage 2: Prepare DNA fragments by restriction enzyme digestion and purification $\bigcirc$ Timing $1 \mathrm{~d}$ Plasmid digesting Timing $\mathbf{4 h}$

$\triangle$ CRITICAL Use $30 \mu \mathrm{g}$ of plasmids for restriction enzyme digesting. The protocol described below will recover enough high-quality DNA fragments for more than two in vitro ligation reactions.

35 Set up a $50-\mu \mathrm{L}$ digest reaction system with appropriate restriction enzymes for each plasmid according to the table below. Scale up the total digestion volume as needed. Table 1 shows the enzymes used for each plasmid.

Restriction enzyme digestion reactions for preparing large amounts of DNA fragments

\begin{tabular}{ll} 
Component & Volume \\
\hline Nuclease-free water & Up to $50 \mu \mathrm{L}$ \\
$10 \times$ Cutsmart buffer & $5 \mu \mathrm{L}$ \\
Restriction enzymes & $1 \mathrm{unit}$ per $\mu \mathrm{g}^{\mathrm{a}}$ \\
Plasmids & TBD $(30 \mu \mathrm{g})$ \\
& \\
\hline
\end{tabular}

${ }^{a}$ The total volume should be $<10 \%$ of the reaction volume

36 Incubate the reaction mixtures in a $37^{\circ} \mathrm{C}$ incubator for $3-4 \mathrm{~h}$.

$\triangle$ CRITICAL STEP The incubation time should not exceed $4 \mathrm{~h}$ to prevent star activities of the restriction enzyme.

37 During the incubation period, prepare a 5-cm-long $0.8 \%$ agarose gel with $3-\mathrm{mm}$-wide well. The reaction of each plasmid will occupy two or three wells of the agarose gel. Prepare seven gels for all seven reactions.

$\triangle$ CRITICAL STEP Always clean the gel dock and the combs thoroughly before casting any new agarose gels. Before gel electrophoresis, always clean the electrophoresis chamber and use fresh gel running buffer to avoid contamination from other experiments.

DNA fragment extraction from gel Timing $\mathbf{2} \mathbf{h}$

38 After digestion, stop the reaction by adding $40 \mu \mathrm{L} 6 \times$ DNA loading buffer to each reaction tube. Mix thoroughly.

39 Load $\sim 34 \mu \mathrm{L}$ of DNA samples to each well of the gel using a P100 pipette. Use one gel for loading one reaction of the DNA samples. Load $5 \mu \mathrm{L}$ 1-kb DNA ladder in a separate well.

$\triangle$ CRITICAL STEP Load the sample slowly to prevent samples from flowing out of the wells.

40 Resolve the DNA fragments by electrophoreses at $120 \mathrm{~V}$ for 30-40 min.

41 Visualize the DNA fragments using a Dark Reader transilluminator.

$\triangle$ CRITICAL STEP Do not use UV light for visualizing the DNA because it causes DNA damage such as breaks in the sugar-phosphate backbone, pyrimidine dimerization and interstrand crosslinks, which will result in failure of downstream RNA transcription. Moreover, UV radiation may introduce undesired mutations into the final recovered viruses.

$\triangle$ CRITICAL STEP Always clean the Dark Reader before placing the gel on the device to avoid contamination from other experiments.

! CAUTION Minimize your own exposure to the lights from the Dark Reader. 
42 Excise the target bands (referring to Table 1 and Fig. 3 for guidance on expected fragment size and expected results) using a clean blade. Place the gel slices containing the targeted DNA fragments into a $15-\mathrm{mL}$ Falcon tube.

43 Extract DNA fragments from the gel slice using a QIAquick gel extraction kit according to the manufacturer's instructions. Use one column for each DNA fragment.

44 At the end of the gel extraction procedures, add $20 \mu \mathrm{L}$ nuclease-free water (prewarmed at $56^{\circ} \mathrm{C}$ ) to the column.

45 Elute the DNA by centrifuging at 14,000 r.p.m. for 2 min at room temperature.

46 Measure the concentration of DNA fragments using a spectrophotometer. Usually, the concentration of DNA fragments is $50-200 \mathrm{ng} \mu \mathrm{L}^{-1}$.

PAUSE POINT The DNA fragments can be used immediately or stored at $4{ }^{\circ} \mathrm{C}$ until use. The purified DNA fragment can be kept at $4{ }^{\circ} \mathrm{C}$ for up to 1 month or stored at $-20^{\circ} \mathrm{C}$ for longer-term storage.

\section{? TROUBLESHOOTING}

\section{Stage 3: In vitro ligation Timing $2.5 \mathrm{~d}$}

Set up in vitro ligation reactions Timing $2 \mathrm{~d}$

47 Prior to reaction setup, calculate the volume of DNA fragments required for assembling the fulllength clone. Equal molar concentrations of each fragment should be used for the ligation in this protocol. The table below shows how to calculate the volume of DNA fragments for assembling $5 \mu \mathrm{g}$ of SARS-CoV-2 full-length DNA.

Calculation of volume of each DNA fragment required for ligation

\begin{tabular}{llll} 
Fragment & Size $(\mathbf{k b})$ & $\begin{array}{l}\text { Mass of each fragment } \\
\text { for assembling 1 } \boldsymbol{\mu g} \\
\text { full-length DNA }\end{array}$ & $\begin{array}{l}\text { Mass of each fragment for } \\
\text { assembling } \mathbf{~} \boldsymbol{\mu g} \text { of full-length } \\
\text { DNA }(\boldsymbol{\mu g})\end{array}$ \\
\hline F1 & 3,644 & 0.12179 & 0.61 \\
F2 & 3,886 & 0.12988 & 0.65 \\
F3 & 4,480 & 0.14973 & 0.75 \\
F4 & 5,607 & 0.18739 & 0.935 \\
F5 & 4,457 & 0.14896 & 0.745 \\
F6 & 4,284 & 0.14318 & 0.715 \\
F7 & 3,565 & 0.11915 & 0.595 \\
Total & 29,921 & 1 & 5
\end{tabular}

48 Prepare the first-step ligation reactions. Set up two separation ligations (A and B) according to the table below. Ligate F1, F2, F3 and F4 in a 0.2-mL PCR tube to produce F1-4 DNA, and ligate F5, F6 and F7 in a separate PCR tube to produce F5-7 DNA. Set up a 40- $\mu \mathrm{L}$ ligation reaction for individual ligation reactions as below.

Reaction system for the first-step ligation

\begin{tabular}{ll} 
Component & Volume \\
\hline Nuclease-free water & Top up to $40 \mu \mathrm{L}$ \\
10× T4 ligation buffer & $4 \mu \mathrm{L}$ \\
T4 DNA ligase & $4 \mu \mathrm{L}$ \\
DNA fragments ${ }^{\mathrm{a}}$ & $\mathrm{TBD}$ \\
& \\
\hline
\end{tabular}

49 Incubate both ligation reactions at $4{ }^{\circ} \mathrm{C}$ for $16-20 \mathrm{~h}$.

50 Set up the second step of ligation. Combine the above two ligation reactions in a new 1.7-mL tube. Top up the reactions with $16 \mu \mathrm{L}$ nuclease-free water, $2 \mu \mathrm{L}$ T4 DNA ligase and $2 \mu \mathrm{L} 10 \times$ ligation buffer to $100 \mu \mathrm{L}$. Mix the reactions thoroughly by gently taping the tube.

51 Incubate the ligation reaction at $4{ }^{\circ} \mathrm{C}$ for another $16-20 \mathrm{~h}$ to produce the full-length SARS-CoV2 DNA. 
Purify the ligation products Timing $1.5 \mathrm{~h}$

52 After ligation, add $100 \mu \mathrm{L}$ phenol:chloroform:isoamyl alcohol to the ligation reaction, and mix the solution by tapping the tube several times.

! CAUTION Organic reagents such as phenol:chloroform:isoamyl alcohol, chloroform and isopropanol are toxic. Chemical fume hood is required for handling such chemicals.

53 Centrifuge the mixture at maximal speed for $1 \mathrm{~min}$ in a benchtop centrifuge.

54 After centrifugation, check that two layers have formed (the aqueous phase on the top and the organic phase at the bottom). Carefully transfer the aqueous phase $(80 \mu \mathrm{L})$ containing the DNAs into a separate $1.7-\mathrm{mL}$ Eppendorf tube.

$\triangle$ CRITICAL STEP Be careful not to transfer the organic phase, which would deteriorate downstream RNA transcription.

55 Add $100 \mu \mathrm{L}$ nuclease-free water to the tube containing the organic phase. Mix the solution by tapping the tube several times. Repeat Steps 52 and 53.

56 Combine the aqueous phase collected from the above two extractions. Add an equal volume of chloroform $(\sim 200 \mu \mathrm{L})$ to the aqueous phase containing DNAs.

57 Mix gently by tapping the tube several times. Centrifuge the tube in a benchtop centrifuge at maximum speed for $1 \mathrm{~min}$.

58 Transfer the upper aqueous phase $(\sim 200 \mu \mathrm{L})$ to a new $1.7-\mathrm{mL}$ tube.

59 Add sodium acetate $(3.0 \mathrm{M}, \mathrm{pH} 5.2)$ to the DNA solution to final concentration of $0.3 \mathrm{M}$.

60 Add an equal volume of isopropanol and mix gently by inverting the tube several times.

$\triangle$ CRITICAL STEP It is important to precipitate DNA at room temperature using isopropanol instead of ethanol to minimize coprecipitation of adenosine triphosphate (ATP) in the T4 ligation buffer. High presence of ATP would interfere with DNA quantification and downstream in vitro transcription.

61 Incubate the mixtures at room temperature for 15-30 min to precipitate DNA.

62 Pellet down the DNA by centrifuging at maximum speed for $15 \mathrm{~min}$ at room temperature in a benchtop centrifuge to pellet DNA.

63 Carefully decant the supernatant.

$\triangle$ CRITICAL STEP The pellet may come out with the supernatant. To prevent loss of the pellet during decanting, save the supernatant in a new tube until you are sure that the precipitated DNA has been recovered.

64 Add $1 \mathrm{~mL} \mathrm{70 \%} \mathrm{ethanol} \mathrm{to} \mathrm{the} \mathrm{pellet.} \mathrm{Centrifuge} \mathrm{at} \mathrm{maximum} \mathrm{speed} \mathrm{for} 5 \mathrm{~min}$ at room temperature and carefully decant the supernatant.

$\triangle$ CRITICAL STEP The pellet may come out with the supernatant. To prevent loss of the pellet during decanting, save the supernatant in a new tube until you are sure that the precipitated DNA has been recovered.

65 Add $1 \mathrm{~mL}>95 \%$ ethanol to the pellet. Centrifuge at maximum speed for $2 \mathrm{~min}$ at room temperature and carefully decant the supernatant.

$\triangle$ CRITICAL STEP The pellet may come out with the supernatant. To prevent loss of the pellet during decanting, save the supernatant in a new tube until you are sure that the precipitated DNA has been recovered.

66 Carefully remove the residual liquid completely with a P100 pipet loaded with $100-\mu \mathrm{L}$ tips, and airdry the pellet for $<5 \mathrm{~min}$.

$\triangle$ CRITICAL STEP Do not touch the pellets. The pellet may stick to the tip.

$\triangle$ CRITICAL STEP Do not overdry the pellet, as this might cause low recovery of the DNA.

67 Add $10 \mu \mathrm{L}$ nuclease-free water (prewarmed at $56^{\circ} \mathrm{C}$ ) to resuspend the DNA.

68 Wait for $1 \mathrm{~min}$ until the DNAs are completely dissolved. Gently tap the tube to mix the DNA. Quickly spin the tube to bring all the liquid down to the bottom.

69 Use $0.5-1 \mu \mathrm{L}$ of samples to measure the quantity and quality of DNA with a spectrometer. Transfer the recovered DNA samples to a new tube containing DNA loading dye. The expected total yield of DNA products is $\sim 3 \mu \mathrm{g}$.

70 Load the recovered DNA samples for agarose gel electrophoresis to examine the full-length DNA. The ligated full-length SARS-CoV-2 DNA should be separated from other DNA fragments in a $0.8 \%$ agarose gel, as shown in Fig. 2.

DAUSE POINT The purified DNAs can be used immediately or stored at $4{ }^{\circ} \mathrm{C}$ for up to a month until use.

? TROUBLESHOOTING 
Preparation of N-gene DNA Timing 1 d

$\triangle$ CRITICAL Coelectroporation with N-gene RNA is used in this protocol because $\mathrm{N}$ protein can enhance the infectivity of coronavirus $\mathrm{RNA}^{5,6,24}$. The SARS-CoV-2 N-gene cDNA is prepared from the plasmid pCC1-CoV-2-F7 via PCR with a pair of primers CoV-T7-N-F (tactgTAATACGACTCAC TATAGGatgtctgataatggaccccaaaatc and polyT-N-R [(t) ${ }_{37}$ aggcctgagttgagtcagcac].

71 Prepare 50- $\mu \mathrm{L}$ PCR reactions according to the instructions of the Platinum SuperFI II PCR master mix. Prepare reactions as a $200 \mu \mathrm{L}$ master solution, and aliquot the solution into four PCR tubes as $50 \mu \mathrm{L}$ per tube, as per the table below.

PCR reactions for amplifying N-gene

\begin{tabular}{ll} 
Component & Volume $(\mu \mathrm{L})$ \\
\hline Nuclease-free water & Top up to 50 \\
2× platinum SuperFI II PCR master mix & 25 \\
Forward primer CoV-T7-N-F & 2.5 \\
Reverse primer polyT-N-R & 2.5 \\
Template DNA (plasmid pCC1-CoV-2-F7) & TBD (1-10 ng)
\end{tabular}

72 Incubate reactions in a thermal cycler according to the thermal cycling program outlined in the table below.

Thermal cycling program for PCR

\begin{tabular}{llll} 
Cycle step & Temperature & Time & Cycles \\
\hline Initial denaturation & $98^{\circ} \mathrm{C}$ & $30 \mathrm{~s}$ & 1 \\
Denaturation & $98^{\circ} \mathrm{C}$ & $10 \mathrm{~s}$ & 35 cycles \\
Annealing & $60^{\circ} \mathrm{C}$ & $10 \mathrm{~s}$ & \\
Extention & $72^{\circ} \mathrm{C}$ & $20 \mathrm{~s}$ & 1 \\
Final extension & $72^{\circ} \mathrm{C}$ & $5 \mathrm{~min}$ & -
\end{tabular}

73 Load $1 \mu \mathrm{L}$ of PCR product (mixed with $6 \times$ DNA loading dye) onto a $0.8 \%$ agarose gel and check the PCR products by gel electrophoresis. Usually, PCR will yield a single DNA band with size of 1,319 bp.

74 Clarify the PCR products using the Microspin G-25 columns according to the manufacturer's instructions to remove extra dNTPs from the PCR reactions.

75 Combine all four clarified PCR reactions $(\sim 200 \mu \mathrm{L})$ in a 1.5-mL Eppendorf tube.

76 Add $200 \mu \mathrm{L}$ phenol:chloroform:isoamyl alcohol 25:24:1. Mix the reactions by vortexing for $5 \mathrm{~s}$.

77 Centrifuge at $>12,000$ r.p.m. for $1 \mathrm{~min}$ at room temperature.

78 Transfer the top aqueous layer to a new 1.7-mL Eppendorf tube.

79 Add $100 \mu \mathrm{L}$ nuclease-free water to the tube containing phenol. Repeat Steps 76 and 77.

80 Combine the aqueous phase collected from the above two extractions. Add an equal volume of chloroform $(\sim 250 \mu \mathrm{L})$ to the aqueous phase containing DNAs. Mix the reactions by vortexing for $5 \mathrm{~s}$.

81 Centrifuge at $>12,000$ r.p.m. for $2 \mathrm{~min}$ at room temperature. Collect the top layer $(\sim 250 \mu \mathrm{L})$ in another 1.7-mL Eppendorf tube.

82 Add $\sim 30 \mu \mathrm{L}$ sodium acetate (3.0 M, pH 5.2) to the DNA solution to final concentration of $0.3 \mathrm{M}$.

83 Add $900 \mu \mathrm{L}$ pure ethanol and $1.2 \mu \mathrm{L}$ glycogen. Mix by vortexing for $5 \mathrm{~s}$.

84 Incubate the tube at $-20{ }^{\circ} \mathrm{C}$ for $>30 \mathrm{~min}$.

85 Centrifuge the tube at $4^{\circ} \mathrm{C}$ at 14,000 r.p.m. for 15 min to pellet the PCR product.

86 Wash the pellet once with $70 \%$ ethanol.

87 Carefully remove the residual liquid completely using a P100 pipet loaded with $100-\mu \mathrm{L}$ tips, and airdry the pellet for $<5$ min.

88 Add $15 \mu \mathrm{L}$ nuclease-free water (prewarmed at $56^{\circ} \mathrm{C}$ ) to resuspend the DNA.

89 Wait for 1 min until the DNA is completely dissolved. Gently tap the tube to mix the DNA. Quickly spin the tube to bring all the liquid down to the bottom. 
90 Use $0.5-1 \mu \mathrm{L}$ of samples to measure the quantity and quality of DNA using a spectrometer. Transfer the recovered DNA samples to a new tube containing DNA loading dye.

91 Load the recovered DNA samples for agarose gel electrophoresis to examine the quality of the purified DNA.

PAUSE POINT The purified DNAs can be used immediately or stored at $-20{ }^{\circ} \mathrm{C}$ until use. ? TROUBLESHOOTING

\section{Stage 4: Prepare full-length RNA and N-gene RNA by in vitro transcription}

In vitro transcription Timing $1 \mathrm{~d}$

$\triangle$ CRITICAL Use mMESSAGE mMACHINE T7 transcription kit to generate SARS-CoV-2 and N-protein RNA

92 Set up the in vitro transcription reactions as shown in the table below. In vitro transcription reaction setup

\begin{tabular}{lll} 
Component & For transcribing full-length RNA & For transcribing N RNA \\
\hline $2 \times$ NTP/CAP & $25 \mu \mathrm{L}$ & $10 \mu \mathrm{L}$ \\
GTP & $7.5 \mu \mathrm{L}$ & $0.75 \mu \mathrm{L}$ \\
$10 \times$ reaction buffer & $5 \mu \mathrm{L}$ & $2 \mu \mathrm{L}$ \\
DNA template & $\mathrm{Up}$ to $7.5 \mu \mathrm{L}$ (use 1-2 $\mu \mathrm{g})$ & $\mathrm{TBD}$ (use $1 \mu \mathrm{g}$ ) \\
Enzyme mix & $5 \mu \mathrm{L}$ & $2 \mu \mathrm{L}$ \\
Nuclease-free water & Top up to $50 \mu \mathrm{L}$ & Top up to $20 \mu \mathrm{L}$
\end{tabular}

93 Incubate the reactions for transcribing SARS-CoV-2 full-length RNA at $32{ }^{\circ} \mathrm{C}$ for $8 \mathrm{~h}$. Incubate the reactions for transcribing SARS-CoV-2 N RNA at $37^{\circ} \mathrm{C}$ for $3 \mathrm{~h}$.

94 Add $1-2 \mu \mathrm{L}$ DNase to digest the DNA templates for $15 \mathrm{~min}$ at $37^{\circ} \mathrm{C}$.

95 Extract and purify the RNA using acid phenol:chloroform according to the instructions of the mMESSAGE mMACHINE T7 transcription kit.

96 After isopropanol precipitation and 70\% ethanol wash, resuspend the pellet with 20-50 $\mu \mathrm{L}$ nuclease-free water.

97 Measure the quantity and quality of DNA using a spectrometer and load $1 \mu \mathrm{L}$ of RNA samples onto a $0.8 \%$ agarose gel to examine the quality of RNA (Fig. $2 b$ ).

98 Aliquot SARS-CoV-2 full-length RNA and N RNA into PCR tubes ( $20 \mu \mathrm{g}$ per tube) and store RNA samples at $-80{ }^{\circ} \mathrm{C}$.

? TROUBLESHOOTING

\section{Stage 5: Electroporation and virus production Timing $1 \mathrm{~h}$ for electroporation and 2-4 $\mathrm{d}$ for recovering viruses}

$\triangle$ CRITICAL This section describes how to recover the SARS-CoV-2 recombinant virus from cell culture via RNA electroporation. Two different methods using either Vero E6 cells alone (option A) or BHK-21 cells and Vero E6 cells (option B) are described separately. In option B, RNA transcripts are electroporated into BHK-21 cells and the electroporated BHK cells are seeded onto a monolayer of Vero E6 cells. The steps involving cell culture should be performed in a sterile environment in a biosafety cabinet.

99 Recover the SARS-CoV-2 recombinant virus from cell culture via RNA electroporation using either Vero E6 cells (option A) or BHK-21 cells (option B).

(A) Electroporation using Vero E6 cells only

(i) Split Vero E6 cells $1 \mathrm{~d}$ before electroporation to ensure $80-90 \%$ confluence the next day. Seed cells in a T-175 flask and grow cells in a $37^{\circ} \mathrm{C}$ incubator with $5 \% \mathrm{CO}_{2}$. Usually, one T175 flask of cells is enough to perform electroporation of two samples.

$\triangle$ CRITICAL Cells maintained in BSL-2 lab should be checked for mycoplasma contamination prior to electroporation. The electroporation and cell culture steps must be strictly performed in BSL-3 laboratories. Use fresh cells with $80-90 \%$ of confluence prior to electroporation to ensure cells are at the exponential growth stage. Using cells that are too confluent and/or old could result in low transfection efficiency and low cell viability after electroporation. 
(ii) Before electroporation, get the following reagents and equipment ready:

- Prewarm PBS, $0.25 \%$ trypsin-EDTA and cell growth medium in a $37^{\circ} \mathrm{C}$ water bath.

- Prechill a 4-mm cuvette and a bottle of PBS on ice.

- Thaw $20 \mu \mathrm{g}$ SARS-CoV-2 and $20 \mu \mathrm{g}$ N RNA on ice.

- Cool down the centrifuge to $4{ }^{\circ} \mathrm{C}$.

(iii) Remove cell culture media from the T175-flask using VACUBOY.

(iv) Add $12 \mathrm{~mL}$ warm PBS to wash the cell monolayer twice.

$\triangle$ CRITICAL STEP Vero E6 cells are easily detached. Do not pipet PBS against cell monolayer.

(v) Discard PBS and add $4 \mathrm{~mL}$ warm $0.25 \%$ trypsin-EDTA to the flask.

(vi) Incubate the flask at $37^{\circ} \mathrm{C}$ for 1 min to detach cells from the flask.

(vii) Add $12 \mathrm{~mL}$ culture medium supplemented with $10 \%$ FBS to neutralize the activities of trypsin.

(viii) Pipet the cell suspension gently several times to make a single-cell suspension.

(ix) Transfer the cell suspension into a 50-mL Falcon tube.

(x) Wash the flask one more time with $12 \mathrm{~mL}$ culture medium. Collect as many of the cells as possible.

(xi) Pellet down the cells by centrifuging at $420 \mathrm{~g}$ for $5 \mathrm{~min}$ at $4{ }^{\circ} \mathrm{C}$.

(xii) Discard the supernatant and resuspend the cells in $20 \mathrm{~mL}$ chilled PBS.

$\triangle$ CRITICAL STEP Keep the cells on ice before electroporation.

(xiii) Take $30 \mu \mathrm{L}$ cell suspension for cell counting by mixing cells with an equal volume of Trypan blue in a $1.7-\mathrm{mL}$ EP tube.

(xiv) Count the cell numbers using Bio-Rad automated cell counter.

(xv) Calculate the total number of cells for electroporation (8 million cells per electroporation) and discard any extra cells.

(xvi) Pellet down the cells by centrifuging at $420 \mathrm{~g}$ for $5 \mathrm{~min}$ at $4{ }^{\circ} \mathrm{C}$.

(xvii) Resuspend the cell pellet with $0.8 \mathrm{~mL}$ chilled $\left(4{ }^{\circ} \mathrm{C}\right)$ electroporation buffer. The concentration of the cells should be $\sim 10^{7}$ cells per $\mathrm{mL}$.

(xviii) In BSL-3, add $20 \mu \mathrm{g}$ SARS-CoV-2 full-length RNA and $20 \mu \mathrm{g}$ N-protein RNA into the chilled 4-mm cuvette.

$\triangle$ CRITICAL STEP Electroporation should be performed in a biosafety cabinet in BSL-3.

(xix) Add $800 \mu \mathrm{L}$ cell suspension and mix gently by pipetting up and down.

$\triangle$ CRITICAL STEP Try to prevent bubbles from forming in the cuvette when mixing cells with RNAs.

(xx) Place the cuvette into the Gene Pulser Xcell electroporation system quickly and apply a single electrical pulse with a setting of $270 \mathrm{~V}$ at $950 \mu \mathrm{F}$ (see equipment setup for more details). Keep the Shockpod in the hood and the rest of the electroporator outside the hood.

(xxi) After electroporation, place the cuvette at room temperature for $5 \mathrm{~min}$ to recover the cells.

(xxii) Gently aspirate the cells out of the cuvette and transfer cells in a new T75 flask containing $15 \mathrm{~mL}$ culture medium supplemented with $10 \%$ FBS.

(xxiii) Gently tilt the flasks left and right to distribute cells evenly.

(xxiv) Incubate the cells in a $37^{\circ} \mathrm{C}$ incubator with $5 \% \mathrm{CO}_{2}$.

(xxv) The next day, change the culture media to fresh medium supplemented with $2 \%$ FBS.

(xxvi) Monitor the cells daily for virus-mediated cytopathic effect (CPE). For recombinant wild-type (WT) SARS-CoV-2, minor CPE will be expected to occur at 24-48 h post-electroporation. Severe CPE occur at 48-72 $\mathrm{h}$ post-transfection. WT SARS-CoV-2 from electroporation (defined as P0 virus) is usually harvested $\sim 40-60 \mathrm{~h}$ post-transfection.

(xxvii) Harvest P0 virus by centrifuging at $1,000 \mathrm{~g}$ for $10 \mathrm{~min}$ at $4{ }^{\circ} \mathrm{C}$. Aliquot the P0 virus as $500 \mu \mathrm{L}$ per tube, and store the viruses in $-80^{\circ} \mathrm{C}$ freezer for future use.

(xxviii) Seed $50-100 \mu \mathrm{L}$ of P0 stock virus into a T175 flask of Vero E6 monolayers.

(xxix) Harvest the supernatants at $48 \mathrm{~h}$ post-infection (defined as P1) by centrifuging at $1,000 \mathrm{~g}$ for $10 \mathrm{~min}$ at $4{ }^{\circ} \mathrm{C}$. Aliquot the $\mathrm{P} 1$ virus as $500-1,000 \mu \mathrm{L}$ per tube. Store the viruses in $-80^{\circ} \mathrm{C}$ freezer for up to 1 year.

(B) Electroporation using BHK-21 cells and Vero E6 cells

$\triangle$ CRITICAL RNA transcripts are electroporated into BHK-21 cells, and the electroporated BHK cells are seeded onto a monolayer of Vero E6 cells. This approach results in higher 
transfection efficiency and better cell viability post-electroporation than using Vero E6 cells alone.

(i) Prepare two T75 flasks of Vero E6 cells and three T75 flasks of BHK-21 cells to be 80-90\% confluent at electroporation. BHK-21 cells are maintained in MEM Alpha $(1 \times)$ supplemented with Glutamax, 5\% FBS and 1\% antibiotics. Vero E6 cells are grown in DMEM media containing $10 \%$ FBS and $1 \%$ antibiotics.

(ii) Before electroporation, replace the culture media of Vero E6 flasks with $8 \mathrm{~mL}$ fresh media containing 5\% FBS and $1 \%$ antibiotics.

(iii) Harvest BHK-21 cells from all eight flasks using the same procedures as described in option A (using Vero E6 cells only).

(iv) Resuspend the BHK-21 cell pellet in $2 \mathrm{~mL}$ cold PBS.

$\triangle$ CRITICAL STEP Keep BHK-21 cells and RNAs on ice throughout.

(v) In a BSL3 lab, mix $20 \mu \mathrm{g}$ N-protein RNA, $20 \mu \mathrm{g}$ SARS-CoV-2 RNA with $800 \mu \mathrm{L}$ BHK-21 cells in the chilled cuvette. For the control sample, mix $20 \mu \mathrm{g} N$-protein RNA with $800 \mu \mathrm{L}$ BHK-21 cells in a separate cuvette.

(vi) Set up the exponential protocol in the electroporator with the following parameters: voltage (V): 850; capacitance: $25 \mu \mathrm{F}$; resistance: $\infty$; cuvette $(\mathrm{mm}): 4$.

(vii) Keep the Shockpod in the hood and the rest of the electroporator outside the hood. Insert the control cuvette into the Shockpod and apply three pulses with a 3-s interval between each pulse.

(viii) Incubate the electroporated cells at room temperature for $5 \mathrm{~min}$.

(ix) Gently aspirate the cells out of the cuvette and transfer to a $15-\mathrm{mL}$ tube containing $2 \mathrm{~mL}$ Vero E6 culture media.

(x) Transfer the cell suspension to each Vero E6 flask.

(xi) Tilt the flasks to distribute cells and incubate at $37^{\circ} \mathrm{C}$ with $\mathrm{CO}_{2}$ until $\mathrm{CPE}$ appears (usually on day 3 or 4 ).

\section{? TROUBLESHOOTING}

\section{Stage 6: Viral whole-genome sequencing Timing 2-3 d}

Viral RNA extraction Timing $2 \mathbf{h}$

100 In a BSL-3 lab, add $200 \mu \mathrm{L}$ virus sample into a 2-mL O-ring capped tube containing 1,000 $\mu \mathrm{L}$ TRIzol LS reagent.

$\triangle$ CRITICAL STEP Tubes used to collect viral RNA must be equipped with screw-top lids and sealing rings to prevent leakage of the virus.

101 Screw down the lid tightly and mix the culture fluid and TRIzol LS thoroughly. Place the tube at room temperature for 5 min to permit disruption of the virus.

PAUSE POINT The TRIzol LS inactivated samples can be stored at $-80{ }^{\circ} \mathrm{C}$ for 1 year without RNA degradation.

102 After careful surface decontamination, bring the samples to the BSL-2 lab for downstream processing.

103 Isolate RNA by following the instructions of TRIzol LS reagent.

104 Finally, dissolve the extracted RNA in $15 \mu \mathrm{L}$ nuclease-free water.

PAUSE POINT The extracted RNA can be used immediately or stored at $-80^{\circ} \mathrm{C}$ for future use (up to several months).

\section{RT-PCR and Sanger sequencing Timing $\mathbf{5} \mathbf{~ h}$}

105 Synthesize the first-strand cDNA from $11 \mu \mathrm{L}$ isolated RNA using SuperScript IV reverse transcriptase (according to the manufacturer's instructions). Random hexamers supplied in the kit are used as primers for the reverse transcription. A total of $20 \mu \mathrm{L}$ first-strand cDNA should be obtained.

PAUSE POINT The cDNA can be used immediately or stored at $-20{ }^{\circ} \mathrm{C}$ for future use.

106 Nine DNA fragments (gF1 to gF9) spanning the entire genome of SARS-CoV-2 are PCR amplified using the Platium SuperFi II DNA polymerase master solutions. For each fragment amplified by PCR, prepare a $50-\mu \mathrm{L}$ reaction containing $2 \mu \mathrm{L}$ cDNA template and a pair of specific primers. The nine primer pairs used for each fragment amplification are shown in the table below. 


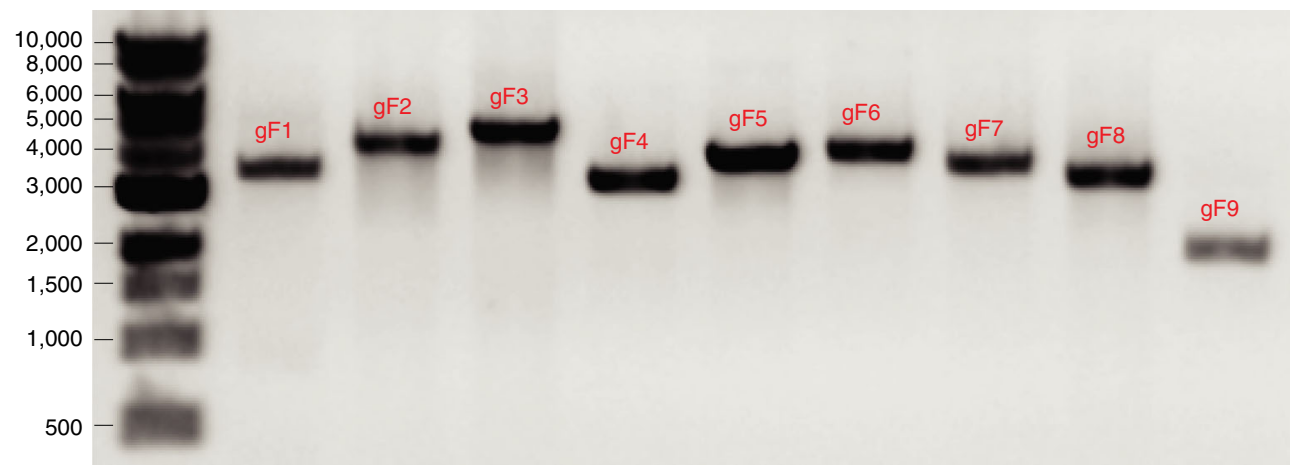

Fig. 4 | Nine PCR amplicons prepared for Sanger sequencing. The DNA ladders (bp) are shown.

Primers and annealing temperature for PCR

\begin{tabular}{|c|c|c|c|c|c|c|c|c|c|}
\hline Fragment & gF1 & gF2 & gF3 & gF4 & gF5 & gF6 & gF7 & gF8 & gF9 \\
\hline $\begin{array}{l}\text { Forward primer } \\
\text { (in } 10 \mu \mathrm{M} \text { ) }\end{array}$ & cov-1V & $\begin{array}{l}\text { cov- } \\
3225 \mathrm{~V}\end{array}$ & $\begin{array}{l}\text { cov- } \\
7382 \mathrm{~V}\end{array}$ & $\begin{array}{l}\text { cov- } \\
11707 V\end{array}$ & $\begin{array}{l}\text { cov- } \\
14618 \mathrm{~V}\end{array}$ & $\begin{array}{l}\text { cov- } \\
18037 \mathrm{~V}\end{array}$ & $\begin{array}{l}\text { cov- } \\
21521 V\end{array}$ & $\begin{array}{l}\text { cov- } \\
25068 \mathrm{~V}\end{array}$ & $\begin{array}{l}\text { cov- } \\
27875 V\end{array}$ \\
\hline $\begin{array}{l}\text { Reverse primer } \\
\text { (in } 10 \mu \mathrm{M} \text { ) }\end{array}$ & $\begin{array}{l}\text { pncov- } \\
\text { R1 }\end{array}$ & $\begin{array}{l}\text { pncov- } \\
\text { F2m-R }\end{array}$ & $\begin{array}{l}\text { pncov- } \\
\text { R3 }\end{array}$ & $\begin{array}{l}\text { cov- } \\
14995 R\end{array}$ & $\begin{array}{l}\text { cov- } \\
18377 R\end{array}$ & $\begin{array}{l}\text { pncov- } \\
\text { R5 }\end{array}$ & $\begin{array}{l}\text { Cov- } \\
25238 R\end{array}$ & $\begin{array}{l}\text { cov- } \\
28099 R\end{array}$ & $\begin{array}{l}\text { pncov- } \\
\text { R7 }\end{array}$ \\
\hline $\begin{array}{l}\text { Annealing } \\
\text { temperature }\end{array}$ & $58^{\circ} \mathrm{C}$ & $58^{\circ} \mathrm{C}$ & $59^{\circ} \mathrm{C}$ & $59^{\circ} \mathrm{C}$ & $54^{\circ} \mathrm{C}$ & $55^{\circ} \mathrm{C}$ & $55^{\circ} \mathrm{C}$ & $55^{\circ} \mathrm{C}$ & $58^{\circ} \mathrm{C}$ \\
\hline $\begin{array}{l}\text { Amplicon size } \\
\text { (base pairs) }\end{array}$ & $3.6 \mathrm{~kb}$ & $4.3 \mathrm{~kb}$ & $4.6 \mathrm{~kb}$ & $3.2 \mathrm{~kb}$ & $3.8 \mathrm{~kb}$ & $4.02 \mathrm{~kb}$ & $3.7 \mathrm{~kb}$ & $3.0 \mathrm{~kb}$ & $2.0 \mathrm{~kb}$ \\
\hline
\end{tabular}

The nucleic acid sequences of nine pairs of primers for PCR are shown in the following table.

\begin{tabular}{|c|c|}
\hline Primer name & Sequence $\left(5^{\prime}-3^{\prime}\right)$ \\
\hline cov-1V & ATTAAAGGTTTATACCTTCCCAGG \\
\hline pncov-R1 & GGGCCGACAACATGAAGACAGTG \\
\hline cov-3225V & CTGTTGGTCAACAAGACGG \\
\hline pncov-F2m-R & CTATTACGTTTGTAACACATCATACATGTAGATGAATTAC \\
\hline cov-7382V & CAAATGGCCCCGATTTCAG \\
\hline pncov-R3 & CAAAGGCTTCAGTAGTATCTTTAGC \\
\hline cov-11707V & AGTTTCTACACAGGAGTTTAG \\
\hline cov-14995R & TGGAAAACCAGCTGATTTGTC \\
\hline cov-14618V & CTACGTGCTTTTCAGTAG \\
\hline cov-18377R & GTAGAAAAACCTAGCTGTAAAGG \\
\hline cov-18037V & AAGCTGAAAATGTAACAGG \\
\hline pncov-R5 & TCGCACTAGAATAAACTCTGAACTC \\
\hline cov-21521V & TGTTATTTCTAGTGATGTTCTTG \\
\hline cov-25238R & CAATCAAGCCAGCTATAAAACC \\
\hline cov-25068V & TCTCTGGCATTAATGCTTC \\
\hline cov-28099R & GATTTAGAACCAGCCTCATCC \\
\hline cov-27875V & TTGTCACGCCTAAACGAAC \\
\hline pncov-R7 & TTTTTTTTTTTTTGTCATTCTCCTAAGAAGC \\
\hline
\end{tabular}

$\triangle$ CRITICAL STEP A DNA polymerase with high fidelity is used to avoid errors occurring during DNA amplification.

107 To check the size of PCR products, run $1 \mu \mathrm{L}$ of each fragment in a $0.8 \%$ agarose gel. Image the gel using a Gel DOC-EZ imager. The expected bands are shown in Fig. 4.

108 Purify the PCR products using the QIAquick PCR purification kit according to the manufacturer's instruction. 
Table 2 | Sequencing primer list

\begin{tabular}{|c|c|c|}
\hline Fragment & Primer name & Sequence $\left(5^{\prime}-3^{\prime}\right)$ \\
\hline \multirow[t]{7}{*}{ gF1 } & $\operatorname{cov}-1 \mathrm{~V}$ & ATTAAAGGTTTATACCTTCCCAGG \\
\hline & cov-655V & AGCTGGTGGCCATAGTTAC \\
\hline & cov-1321V & AGGTGCCACTACTTGTGG \\
\hline & cov-1925V & CTGCTCAAAATTCTGTGCG \\
\hline & cov-2572V & CTACTAGTGAAGCTGTTGAAGC \\
\hline & cov-3225V & CTGTTGGTCAACAAGACGG \\
\hline & cov-528R & AGCTCAACCATAACATGACC \\
\hline \multirow[t]{8}{*}{ gF2 } & cov-3225V & CTGTTGGTCAACAAGACGG \\
\hline & cov-3824V & GTTTCAAGCTTTTTGGAAATG \\
\hline & cov-4431V & TGCCTGTCTGTGTGGAAAC \\
\hline & cov-4990V & CAACATTAACCTCCACACGC \\
\hline & cov-5525V & ACTTGTGGACAACAGCAG \\
\hline & cov-6109V & GAAACCTGCTTCAAGAGAG \\
\hline & cov-6737V & ACACGGTGTTTAAACCGTG \\
\hline & cov-7382V & CAAATGGCCCCGATTTCAG \\
\hline \multirow[t]{9}{*}{ gF3 } & cov-7382V & CAAATGGCCCCGATTTCAG \\
\hline & cov-7930V & TCAGCGTCTGTTTACTACAG \\
\hline & cov-8481V & CTTTTAAGTTGACATGTGCAAC \\
\hline & cov-8995V & ATCAGCTTGTGTTTTGGC \\
\hline & cov-9534V & CTGTACTCTGTTTAACACC \\
\hline & cov-10094V & GAGGGTTGTATGGTACAAG \\
\hline & cov-10680V & ACGCTGCTGTTATAAATGG \\
\hline & cov-11188V & ACСTTCTCTTGCCACTG \\
\hline & cov-11707V & AGTTTCTACACAGGAGTTTAG \\
\hline \multirow[t]{6}{*}{ gF4 } & cov-11707V & AGTTTCTACACAGGAGTTTAG \\
\hline & cov-12205V & GAAGAAGTCTTTGAATGTGG \\
\hline & cov-12806V & GTACTTGCACTGTTATCCG \\
\hline & cov-13441V & GTCAGCTGATGCACAATCG \\
\hline & cov-14062V & GATAATCAAGATCTCAATGG \\
\hline & cov-14618V & CTACGTGCTTTTCAGTAG \\
\hline \multirow[t]{7}{*}{ gF5 } & cov-14618V & CTACGTGCTTTTCAGTAG \\
\hline & cov-15170V & ATCAATAGCCGCCACTAG \\
\hline & cov-15677V & ACGCATATTTGCGTAAAC \\
\hline & cov-16273V & TCATTAAGATGTGGTGCTTG \\
\hline & cov-16853V & GTGATGCTGTTGTTTACCG \\
\hline & cov-17444V & СTCAATTACCTGCACCAC \\
\hline & cov-18037V & AAGCTGAAAATGTAACAGG \\
\hline \multirow[t]{7}{*}{ gF6 } & cov-18037V & AAGCTGAAAATGTAACAGG \\
\hline & cov-18588V & TGTCTTATGGGCACATGG \\
\hline & cov-19211V & GATATCCTGCTAATTCCATTG \\
\hline & cov-19840V & ATTTGGGTGTGGACATTG \\
\hline & cov-20459V & AACAGATGCGCAAACAGG \\
\hline & cov-20934V & TACGCTGCTTGTCGATTC \\
\hline & cov-21521V & TGTTATTTCTAGTGATGTTCTTG \\
\hline \multirow[t]{7}{*}{ gF7 } & cov-21521V & TGTTATTTCTAGTGATGTTCTTG \\
\hline & cov-22092V & TGGACCTTGAAGGAAAAC \\
\hline & cov-22685V & TCCACTTTTAAGTGTTATGGAG \\
\hline & cov-23203V & AGGCACAGGTGTTCTTAC \\
\hline & cov-23840V & GTACACAATTAAACCGTGC \\
\hline & cov-24428V & CACAAGCTTTAAACACGC \\
\hline & cov-25068V & TCTCTGGCATTAATGCTTC \\
\hline gF8 & cov-25068V & TCTCTGGCATTAATGCTTC \\
\hline
\end{tabular}


Table 2 (continued)

\begin{tabular}{|c|c|c|}
\hline Fragment & Primer name & Sequence $\left(5^{\prime}-3^{\prime}\right)$ \\
\hline \multirow{11}{*}{ gF9 } & cov-25624V & CACTTTGTTTGCAACTTGC \\
\hline & cov-26245V & CATTCGTTTCGGAAGAGAC \\
\hline & cov-26778V & GTCTTGTAGGCTTGATGTG \\
\hline & cov-27372V & ATGGAGATTGATTAAACGAAC \\
\hline & cov-27875V & TTGTCACGCCTAAACGAAC \\
\hline & cov-25068V & TCTCTGGCATTAATGCTTC \\
\hline & cov-27875V & TTGTCACGCCTAAACGAAC \\
\hline & cov-28404V & GTTTACCCAATAATACTGCG \\
\hline & cov-28994V & CAACAAGGCCAAACTGTC \\
\hline & cov-29611V & GTGCAGAATGAATTCTCG \\
\hline & F7-Avrll-R & GAAGTCCAGCTTCTGGCC \\
\hline
\end{tabular}

109 Elute final DNA in $60 \mu \mathrm{L}$ nuclease-free water (prewarmed at $56^{\circ} \mathrm{C}$ ), and determine the concentration using spectrometer.

- PAUSE POINT The cDNA can be used immediately or stored at $-20{ }^{\circ} \mathrm{C}$ for future use.

110 Prepare DNA and primers for Sanger sequencing (outsourced or performed in-house). Table 2 lists the primers for Sanger sequencing of corresponding DNA fragments.

\section{Troubleshooting}

Troubleshooting advice can be found in Table 3 .

Table 3 | Troubleshooting table

$\begin{array}{lll}\text { Step Problem } & \text { Possible reason } & \text { Possible solution }\end{array}$

$10 \quad$ No colonies occur after Use of incorrect competent cells transformation

24

Incorrect sizes of fragments occur after restriction enzyme digestion

$33 \quad$ Plasmid yield from Maxiprep is low

45 Low DNA recovery after gel extraction

68
Use of incorrect concentration of antibiotics

Plasmids are degraded or badly preserved

Wrong colonies have been picked up

Cultures have been grown for too long

Potential mutations have been introduced into the plasmids during the PCR or mutagenesis Bacterial cultures are not well prepared

Low quality of the Maxprep plasmids due to bacterial RNA and/or RNA contamination in the plasmid preparation

Incomplete digestion by the restriction enzymes

Ligation has failed
No full-length SARS-CoV-2 DNA fragments recovered
Check you are using the correct competent cells for corresponding plasmids. If using competent cells other than the recommended cells, results are not guaranteed

Check the concentration and shelf life of the antibiotics. The antibiotics should not have passed their expiration date

Prepare new plasmids with concentration between 1 and $10{\mathrm{ng} \mu \mathrm{L}^{-1}}^{-1}$

Discard the colonies and pick up new colonies

Grow and induce cultures as recommended in the Procedure

Pick up new colonies for screening. Grow the culture at 25 or $30{ }^{\circ} \mathrm{C}$ for $48 \mathrm{~h}$ instead of at $37^{\circ} \mathrm{C}$ overnight

Reprepare the bacterial cultures. Carefully check the LB media, antibodies, preservation conditions of the glycerol stocks and shaker settings. If possible, scale up culture to $>1 \mathrm{~L}$

Follow the Maxprep procedures carefully

Check the expiration date of the restriction enzymes

Re-set up the ligation. Always run a portion of purified full-length DNA $(1 \mu \mathrm{L})$ on a gel to check the ligation efficiency. Large blobs of full-length genomic DNA are

Table continued 
Table 3 (continued)

Step Problem

\section{Possible solution}

\begin{tabular}{|c|c|c|c|}
\hline & & & $\begin{array}{l}\text { needed for success. If full-length DNA appears as a } \\
\text { thin band, perform DNA ligation at } 16^{\circ} \mathrm{C} \text { for } 18 \mathrm{~h}\end{array}$ \\
\hline & & DNA has degrade & Do not store the DNA fragments at $-80^{\circ} \mathrm{C}$ \\
\hline & & $\begin{array}{l}\text { Acidified or expired phenol used } \\
\text { during the purification. }\end{array}$ & $\begin{array}{l}\text { Use the phenol as recommended. Do not use } \\
\text { acidified phenol }\end{array}$ \\
\hline \multirow[t]{2}{*}{89} & Low yield of $\mathrm{N}$-gene DNA & PCR of N-gene did not work. & $\begin{array}{l}\text { Re-set up the PCR exactly as recommended in the } \\
\text { Procedure }\end{array}$ \\
\hline & & $\begin{array}{l}\text { Nonspecific amplification has } \\
\text { occurred during the PCR }\end{array}$ & $\begin{array}{l}\text { Optimize the PCR conditions if needed. Run a portion } \\
\text { of PCR product }(1 \mu \mathrm{L}) \text { on a gel to check the quality of } \\
\text { the PCR product. There should be only one DNA band } \\
\text { after gel electrophoresis }\end{array}$ \\
\hline \multirow[t]{4}{*}{96} & RNA recovery is low & Poor quality of DNA template & Reprepare the ligation and purify high-quality DNA \\
\hline & & Low input of DNA template & $\begin{array}{l}\text { Increase the in vitro transcription time or the amounts } \\
\text { of input template }\end{array}$ \\
\hline & & $\begin{array}{l}\text { Contamination of } \\
\text { residual phenol }\end{array}$ & $\begin{array}{l}\text { Avoid transferring the organic phase during } \\
\text { purification }\end{array}$ \\
\hline & & $\begin{array}{l}\text { Too much residual ATP carried } \\
\text { over from the ligation }\end{array}$ & $\begin{array}{l}\text { Follow the protocol as recommended. Do not use } \\
\text { alcohol for precipitation. Good quality of purified DNA } \\
\text { (A260/A230>1, A260/280 1.8) is needed for } \\
\text { success }\end{array}$ \\
\hline \multirow[t]{3}{*}{97} & No CPE/virus at given time & Poor RNA quality & Extend monitoring time after electroporation \\
\hline & & $\begin{array}{l}\text { Only a small amount of full- } \\
\text { length RNA transcribed }\end{array}$ & $\begin{array}{l}\text { Increase the amount of RNA transcripts (up to } 60 \mu \mathrm{g} \text { ) } \\
\text { for transfection }\end{array}$ \\
\hline & & $\begin{array}{l}\text { Engineered mutations have } \\
\text { significantly attenuated viral } \\
\text { replication }\end{array}$ & $\begin{array}{l}\text { Use other approaches (RT-PCR or } \\
\text { immunofluorescence) to detect the production of } \\
\text { viruses }\end{array}$ \\
\hline 97 & $\begin{array}{l}\text { Significant cell death after } \\
\text { electroporation }\end{array}$ & $\begin{array}{l}\text { Cells are too overgrown prior to } \\
\text { transfection }\end{array}$ & $\begin{array}{l}\text { Always use fresh cells with } 80-90 \% \text { confluence prior } \\
\text { to electroporation }\end{array}$ \\
\hline 108 & $\begin{array}{l}\text { Yield of DNA fragments for } \\
\text { sequencing is low }\end{array}$ & Virus titer is low & $\begin{array}{l}\text { Increase the input of cDNA template for PCR or pool } \\
\text { more viruses for RNA extraction }\end{array}$ \\
\hline \multirow[t]{2}{*}{108} & $\begin{array}{l}\text { Undesired mutations occur } \\
\text { in the viral genome }\end{array}$ & $\begin{array}{l}\text { Mutations occurred during } \\
\text { plasmid propagation in } E \text {. coli }\end{array}$ & $\begin{array}{l}\text { Sequence the plasmids from Maxiprep. Use correct } \\
\text { ones to recover the virus }\end{array}$ \\
\hline & & $\begin{array}{l}\text { Random cell-adaptive mutations } \\
\text { occurred after electroporation }\end{array}$ & $\begin{array}{l}\text { Prepare a new batch of RNA transcripts and redo the } \\
\text { electroporation. Use the WT strain as control }\end{array}$ \\
\hline
\end{tabular}

a

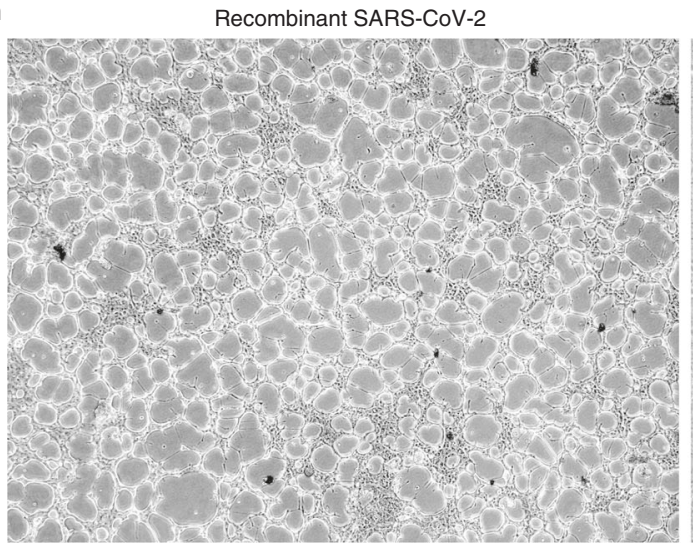

Mock

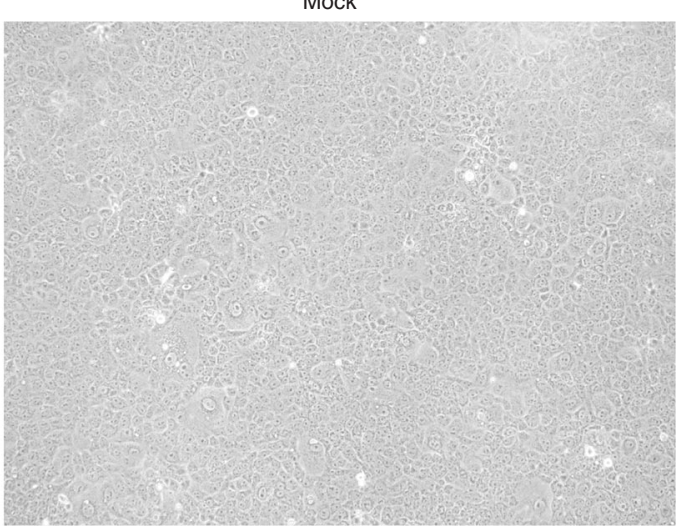

b

\begin{tabular}{cccl}
\hline Genome position & Isolate strain WA1 & Recombinant SARS-CoV-2 & Description \\
\hline 7,486 & $\mathrm{~A}$ & $\mathrm{~T}$ & Molecular marker \\
7,489 & $\mathrm{~T}$ & $\mathrm{~A}$ & Molecular marker \\
18,060 & $\mathrm{~T}$ & $\mathrm{C}$ & Molecular marker \\
\hline
\end{tabular}

Fig. 5 | Characterization of recombinant SARS-CoV-2. a, Bright-field images of the recombinant SARS-CoV-2-infected Vero E6 cells obtained using EVOS M5000 imaging system with 10× objective. Cytopathic effects appeared on day 2 after cells were inoculated with recovered SARS-CoV-2 PO virus. b, Sequencing results for recombinant SARS-CoV-2. 


\section{Timing}

Stage 1, propagation of plasmids containing SARS-CoV-2 fragments

Steps 1-10, chemical transformation: $2 \mathrm{~h}$

Steps 11-15, colony screen: $1 \mathrm{~d}$ or overnight

Steps 16-20, plasmid Miniprep: 1-2 h

Steps 21-25, plasmid validation by restriction enzyme digestion: $2 \mathrm{~h}$

Steps 26-34, plasmid Maxiprep: $24 \mathrm{~h}$

Stage 2, prepare DNA fragments by restriction enzyme digestion and purification

Steps 35-37, plasmid digesting: $4 \mathrm{~h}$

Steps 38-46, DNA fragment extraction from gel: $2 \mathrm{~h}$

Stage 3 , in vitro ligation

Steps 47-51, set up in vitro ligation reactions: $2 \mathrm{~d}$

Steps $52-70$, purify the ligation products: $1.5 \mathrm{~h}$

Steps 71-91, preparation of N-gene DNA: $1 \mathrm{~d}$

Stage 4, prepare full-length RNA and N-gene RNA by in vitro transcription

Steps 92-98, in vitro transcription: $1 \mathrm{~d}$

Stage 5, electroporation and virus production

Step $99,1 \mathrm{~h}$ for electroporation and $2-4 \mathrm{~d}$ for recovering viruses

Stage 6, viral whole-genome sequencing

Steps 100-104, viral RNA extraction: $2 \mathrm{~h}$

Steps 105-110, RT-PCR and Sanger sequencing: $5 \mathrm{~h}$

\section{Anticipated results}

This protocol efficiently produces recombinant SARS-CoV-2 viruses. The recovered virus can cause significant CPE on Vero E6 (Fig. 5a). The engineered molecular markers with no other mutations are retained in the recombinant SARS-CoV-2 genome (Fig. 5b). The recombinant virus can generate similar plaque morphologies and replication kinetics as the clinical isolate strain WA1 on Vero E6 cells ${ }^{3}$.

\section{Reporting Summary}

Further information on research design is available in the Nature Research Reporting Summary linked to this article.

\section{Data availability}

Data that support use of this protocol are reported in previous publications ${ }^{3}$. The seven plasmids of SARS-CoV-2 have been deposited to the World Reference Center for Emerging Viruses and Arboviruses (https://www.utmb.edu/wrceva) at UTMB for distribution.

\section{References}

1. Gralinski, L. E. \& Menachery, V. D. Return of the coronavirus: 2019-nCoV. Viruses https://doi.org/10.3390/ v12020135 (2020).

2. Muruato, A. E. et al. A high-throughput neutralizing antibody assay for COVID-19 diagnosis and vaccine evaluation. Nat. Commun. 11, 4059 (2020).

3. Xie, X. et al. An Infectious cDNA Clone of SARS-CoV-2. Cell Host Microbe 27, 841-848 e843 (2020).

4. Xie, X. et al. A nanoluciferase SARS-CoV-2 for rapid neutralization testing and screening of anti-infective drugs for COVID-19. Nat. Commun. 11, 5214 (2020).

5. Yount, B. et al. Reverse genetics with a full-length infectious cDNA of severe acute respiratory syndrome coronavirus. Proc. Natl Acad. Sci. USA 100, 12995-13000 (2003).

6. Yount, B., Denison, M. R., Weiss, S. R. \& Baric, R. S. Systematic assembly of a full-length infectious cDNA of mouse hepatitis virus strain A59. J. Virol. 76, 11065-11078 (2002).

7. Yount, B., Curtis, K. M. \& Baric, R. S. Strategy for systematic assembly of large RNA and DNA genomes: transmissible gastroenteritis virus model. J. Virol. 74, 10600-10611 (2000).

8. Harcourt, J. et al. Severe acute respiratory syndrome coronavirus 2 from patient with 2019 novel coronavirus disease, United States. Emerg. Infect. Dis. https://doi.org/10.3201/eid2606.200516 (2020).

9. Johnson, B. A. et al. Furin cleavage site is key to SARS-CoV-2 pathogenesis. Preprint at bioRxiv https://doi. org/10.1101/2020.08.26.268854 (2020).

10. Plante, J. A. et al. Spike mutation D614G alters SARS-CoV-2 fitness. Nature https://doi.org/10.1038/s41586020-2895-3 (2020). 
11. Almazan, F. et al. Coronavirus reverse genetic systems: infectious clones and replicons. Virus Res. 189, 262-270 (2014).

12. Becker, M. M. et al. Synthetic recombinant bat SARS-like coronavirus is infectious in cultured cells and in mice. Proc. Natl Acad. Sci. USA 105, 19944-19949 (2008).

13. Menachery, V. D. et al. A SARS-like cluster of circulating bat coronaviruses shows potential for human emergence. Nat. Med. 21, 1508-1513 (2015).

14. Menachery, V. D. et al. SARS-like WIV1-CoV poised for human emergence. Proc. Natl Acad. Sci. USA 113, 3048-3053 (2016).

15. Scobey, T. et al. Reverse genetics with a full-length infectious cDNA of the Middle East respiratory syndrome coronavirus. Proc. Natl Acad. Sci. USA 110, 16157-16162 (2013).

16. Sahin, U. et al. COVID-19 vaccine BNT162b1 elicits human antibody and TH1 T cell responses. Nature 586, 594-599 (2020).

17. Mulligan, M. J. et al. Phase I/II study of COVID-19 RNA vaccine BNT162b1 in adults. Nature 586, 589-593 (2020).

18. Walsh, E. E. et al. Safety and immunogenicity of two RNA-based Covid-19 vaccine candidates. N. Engl. J. Med. https://doi.org/10.1056/NEJMoa2027906 (2020).

19. Thi Nhu Thao, T. et al. Rapid reconstruction of SARS-CoV-2 using a synthetic genomics platform. Nature 582, 561-565 (2020).

20. Menachery, V. D. et al. Combination attenuation offers strategy for live attenuated coronavirus vaccines. J. Virol. https://doi.org/10.1128/JVI.00710-18 (2018).

21. Menachery, V. D. et al. MERS-CoV accessory ORFs play key role for infection and pathogenesis. mBio https://doi.org/10.1128/mBio.00665-17 (2017).

22. Menachery, V. D. et al. Trypsin treatment unlocks barrier for zoonotic bat coronavirus infection. J. Virol. https://doi.org/10.1128/JVI.01774-19 (2020).

23. Hou, Y. J. et al. SARS-CoV-2 reverse genetics reveals a variable infection gradient in the respiratory tract. Cell 182, 1-18 (2020).

24. Curtis, K. M., Yount, B. \& Baric, R. S. Heterologous gene expression from transmissible gastroenteritis virus replicon particles. J. Virol. 76, 1422-1434 (2002).

\section{Acknowledgements}

X.X. was partially supported by NIH5UC7AI094660. V.D.M. was supported by NIH and NIAID grants AI153602 and AG049042, and STARs Award provided by the University of Texas System. P.-Y.S. was supported by NIH grants AI142759, AI134907, AI145617 and UL1TR001439, and awards from the Sealy \& Smith Foundation, Kleberg Foundation, the John S. Dunn Foundation, the Amon G. Carter Foundation, the Gilson Longenbaugh Foundation, and the Summerfield Robert Foundation.

\section{Author contributions}

X.X., V.D.M. and P.-Y.S. designed and supervised the project and provided funding for the project. X.X., K.G.L., X.Z., M.N.V., V.D.M. and P.-Y.S. wrote the manuscript. All authors reviewed and approved the manuscript.

\section{Competing interests}

X.X., V.D.M. and P.-Y.S. have filed a patent on the reverse genetic system of SARS-CoV-2 and reporter SARS-CoV-2. The remining authors declare no competing interests.

\section{Additional information}

Supplementary information The online version contains supplementary material available at https://doi.org/10.1038/s41596-021-00491-8. Correspondence and requests for materials should be addressed to V.D.M. or P.-Y.S.

Peer review information Nature Protocols thanks Jasper Chan and Ailong Huang for their contribution to the peer review of this work. Reprints and permissions information is available at www.nature.com/reprints.

Publisher's note Springer Nature remains neutral with regard to jurisdictional claims in published maps and institutional affiliations.

Received: 14 October 2020; Accepted: 4 January 2021;

Published online: 29 January 2021

\section{Related links}

Key references using this protocol

Xie, X. et al. Cell Host Microbe 27, 841-848 e843 (2020): https://doi.org/10.1016/j.chom.2020.04.004

Johnson, B. A. et al. Preprint at bioRxiv (2020): https://doi.org/10.1101/2020.08.26.268854

Plante, J. A. et al. Nature (2020): https://doi.org/10.1038/s41586-020-2895-3 


\section{Reporting Summary}

Nature Research wishes to improve the reproducibility of the work that we publish. This form provides structure for consistency and transparency in reporting. For further information on Nature Research policies, see our Editorial Policies and the Editorial Policy Checklist.

\section{Statistics}

For all statistical analyses, confirm that the following items are present in the figure legend, table legend, main text, or Methods section.

n/a Confirmed

\ $\square$ The exact sample size $(n)$ for each experimental group/condition, given as a discrete number and unit of measurement

$\bigotimes \square$ A statement on whether measurements were taken from distinct samples or whether the same sample was measured repeatedly

$\square$ The statistical test(s) used AND whether they are one- or two-sided

$\triangle \square$ Only common tests should be described solely by name; describe more complex techniques in the Methods section.

Х $\square$ A description of all covariates tested

Х $\square$ A description of any assumptions or corrections, such as tests of normality and adjustment for multiple comparisons

$\triangle$ A full description of the statistical parameters including central tendency (e.g. means) or other basic estimates (e.g. regression coefficient)

AND variation (e.g. standard deviation) or associated estimates of uncertainty (e.g. confidence intervals)

$\triangle$ For null hypothesis testing, the test statistic (e.g. $F, t, r$ ) with confidence intervals, effect sizes, degrees of freedom and $P$ value noted

Give P values as exact values whenever suitable.

Х $\square$ For Bayesian analysis, information on the choice of priors and Markov chain Monte Carlo settings

Х $\square$ For hierarchical and complex designs, identification of the appropriate level for tests and full reporting of outcomes

Х $\square$ Estimates of effect sizes (e.g. Cohen's $d$, Pearson's $r$ ), indicating how they were calculated

Our web collection on statistics for biologists contains articles on many of the points above.

\section{Software and code}

Policy information about availability of computer code

\section{Data collection not applicable}

Data analysis not applicable

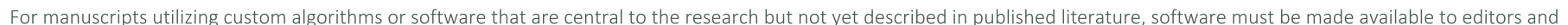

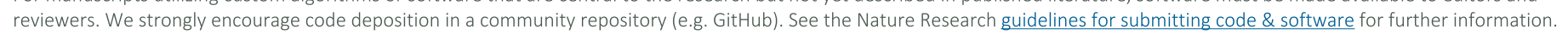

\section{Data}

Policy information about availability of data

All manuscripts must include a data availability statement. This statement should provide the following information, where applicable:

- Accession codes, unique identifiers, or web links for publicly available datasets

- A list of figures that have associated raw data

- A description of any restrictions on data availability

Similar data that support the this study are reported in previous publications (ref.3). The seven plasmids of SARS-CoV-2 has been deposited to the World Reference Center for Emerging Viruses and Arboviruses (https://www.utmb.edu/wrceva) at UTMB for distribution. 


\section{Field-specific reporting}

Please select the one below that is the best fit for your research. If you are not sure, read the appropriate sections before making your selection. $\bigotimes$ Life sciences Behavioural \& social sciences Ecological, evolutionary \& environmental sciences

\section{Life sciences study design}

All studies must disclose on these points even when the disclosure is negative.
Sample size
not applicable
Data exclusions
All data are included in the study.
Replication
Data has been repeated at least once with similar observation
Randomization
not applicable
Blinding
not applicable

\section{Reporting for specific materials, systems and methods}

We require information from authors about some types of materials, experimental systems and methods used in many studies. Here, indicate whether each material, system or method listed is relevant to your study. If you are not sure if a list item applies to your research, read the appropriate section before selecting a response.
Materials \& experimental systems
n/a Involved in the study
Х $\square$ Antibodies
$\square \bigotimes$ Eukaryotic cell lines
\ $\square$ Palaeontology and archaeology
$\triangle \square$ Animals and other organisms
\ $\square$ Human research participants
\ $\square$ Clinical data
$\bigotimes \square$ Dual use research of concern

Methods

$\mathrm{n} / \mathrm{a}$ Involved in the study

X ChIP-seq

Х $\square$ Flow cytometry

\section{Eukaryotic cell lines}

Policy information about cell lines

Cell line source(s)

BHK-21 cells (ATCC ${ }^{\circledR}$ CCL-10) and Vero E6 cells (ATCC ${ }^{\circledR}$ CRL-1586) were obtained from ATCC

Authentication

ATCC have comprehensively performed authentication on cell lines. A549-ACE2 cells were established in UTMB and has been validated for SARS infection.

Mycoplasma contamination

All cell lines were tested negative for mycoplasma.

Commonly misidentified lines

(See ICLAC register)

not applicable 